\title{
Upper Paleozoic mafic and intermediate volcanic rocks of the Mount Pleasant caldera associated with the Sn-W deposit in southwestern New Brunswick (Canada): Petrogenesis and metallogenic implications
}

Jaroslav Dostal $^{1 \mathrm{a}}$ and Pierre Jutras ${ }^{1}$

1. Department of Geology, Saint Mary's University, Halifax, Nova Scotia B3H, Canada

a. Corresponding author: e-mail: jdostal@ smu.ca; phone: 902-420-5747 


\begin{abstract}
Upper Paleozoic ( 365 Ma) mafic and intermediate volcanic rocks of the Piskahegan Group constitute a subordinate part of the Mount Pleasant caldera, which is associated with a significant polymetallic deposit (tungsten-molybdenum-bismuth zones $33 \mathrm{Mt}$ ore with $0.21 \% \mathrm{~W}, 0.1 \%$ Mo and $0.08 \% \mathrm{Bi}$ and tin-indium zones $~ 4.8 \mathrm{Mt}$ with $0.82 \% \mathrm{Sn}$ and $129 \mathrm{~g} / \mathrm{t} \mathrm{In}$ ) in southwestern New Brunswick (Canada). The epicontinental caldera complex formed during the opening of the late Paleozoic Maritimes Basin in the northern Appalachians. The mafic and intermediate rocks make up two compositionally distinct associations. The first association includes evolved riftrelated continental tholeiitic basalts, and the second association comprises calc-alkaline andesites, although both associations were emplaced penecontemporaneously. The basalts have low Mg\# 0.34-0.40, smooth chondrite-normalized REE patterns with $(\mathrm{La} / \mathrm{Yb})_{\mathrm{n}} \sim 5-6$, primitive mantle-normalized trace element patterns without noticeable negative $\mathrm{Nb}$ - $\mathrm{Ta}$ anomalies, and their $\varepsilon_{\mathrm{Nd}(\mathrm{T})}$ ranges from +2.5 to +2.2 . The basalts were generated by partial melting of a transition zone between spinel and garnet mantle peridotite at a depth of $\sim 70-90 \mathrm{~km}$. The calc-alkaline andesites of the second association have chondrite-normalized REE patterns that are more fractionated, with $(\mathrm{La} / \mathrm{Yb})_{\mathrm{n}} \sim 7-8.5$, but without significant negative Eu anomalies. Compared to the basaltic rocks, they have lower $\varepsilon_{\mathrm{Nd}(\mathrm{T})}$ values, ranging from +0.5 to +1.9 , and their mantlenormalized trace element plots show negative $\mathrm{Nb}$-Ta anomalies. The $\varepsilon_{\mathrm{Nd}(\mathrm{T})}$ values display negative correlations with indicators of crustal contamination, such as $\mathrm{Th} / \mathrm{La}, \mathrm{Th} / \mathrm{Nb}$ and $\mathrm{SiO}_{2}$. The andesitic rocks are interpreted to have formed by assimilation-fractional crystallization processes, which resulted in the contamination of a precursor basaltic magma with crustal material. The parent basaltic magma for both suites underwent a different evolution. The tholeiitic basalts experienced shallow-seated fractional crystallization and evolved along a tholeiitic trend of "early iron" enrichment (non-oxic conditions). The contaminated magma of the second association followed a calc-alkaline fractionation trend of "no iron" enrichment (oxidizing conditions) characterized by a high $\mathrm{P}_{\mathrm{H} 2 \mathrm{O}}$ and $\mathrm{P}_{\mathrm{O} 2}$ environment at the mid-crust levels. The Piskahegan Group, which is associated with an important polymetallic mineral deposit, differs from the numerous non-mineralized rift-related volcanic suites of the regional Upper Devonian to Lower Carboniferous successions in the Maritimes Basin by the presence of a
\end{abstract}


significant amount of coeval calc-alkaline andesite, which may be an indicator of potential mineralization.

\section{Introduction}

Felsic rocks of continental rift-related magmatic settings have been the focus of extensive investigation and numerous publications in part because they may host rare metal mineralization, which in some cases are of economic significance (e.g., Richardson and Birkett, 1996; Cerny et al. 2005; Linnen and Cuney, 2005). These rocks are commonly associated with a compositionally wide variety of mafic and intermediate rocks (e.g., Nekvasil et al., 2000). Much is still unknown about the processes that lead to the diversity of magmas within such bimodal series and about the global diversity of intraplate magmatic suites. In mineralized bimodal complexes where felsic rocks are dominant, the subordinate mafic and intermediate rocks are commonly only poorly known, although they might provide important information on the tectonic environment of such bimodal associations, as well as on the origin of the felsic rocks and their mineralization, thus providing clues for the exploration for rare metal deposits. One such suite is the upper Paleozoic Piskahegan Group of southwestern New Brunswick (Canada). The latter group forms a volcanic caldera complex (e.g., McCutcheon, 1990; McCutcheon et al., 1997; Thorne et al., 2013) that is spatially and genetically associated with the Mount Pleasant polymetallic deposit (tungsten-molybdenum-bismuth zones containing $33 \mathrm{Mt}$ ore with $0.21 \%$ $\mathrm{W}, 0.1 \% \mathrm{Mo}$ and $0.08 \% \mathrm{Bi}$ and tin-indium zones $\sim 4.8 \mathrm{Mt}$ with $0.82 \% \mathrm{Sn}$ and $129 \mathrm{~g} / \mathrm{t} \mathrm{In}$ ). The deposit is recognized as the world's largest known undeveloped resource of indium (Sinclair et al., 2006; Thorne et al., 2013). To contribute to the debate on the origin of these bimodal suites, we have investigated mafic and intermediate volcanic rocks of the Mount Pleasant caldera (Figs. 1 and 2). Major and trace elements in these rocks, as well as neodymium isotopes, may provide information related not only to the origin of the bimodal suite and its mineralization, but also on the nature of the mantle source (e.g., DePaolo, 1988). Such data are also useful to evaluate the composition of the subcontinental lithospheric mantle (SCLM).

The purpose of this paper is: (1) to present geochemical data on the mafic and intermediate volcanic rocks of the Mount Pleasant caldera, including major and trace elements 
and $\mathrm{Nd}$ isotopic ratios, (2) to constrain the origin of the rocks in the caldera, (3) to investigate the differences between mineralized and barren Devonian to Carboniferous bimodal volcanic suites in this part of the Northern Appalachians, (4) to evaluate the nature of the SCLM, and (5) to compare this information with data from time equivalent basaltic rocks of New Brunswick and Nova Scotia, which belong to the peri-Gondwanan Gander and Avalon terranes of the Appalachians of eastern North America. The comparison of SCLM properties in two neighboring exotic terranes could reveal whether or not both terranes were underlain by the same SCLM during the Paleozoic and thus contribute to the Ganderian controversy (i.e. whether or not the Gander and Avalon zones represent distinct terranes; e.g.,van Staal and Barr, 2012; Dostal et al., 2016a).

\section{Geological setting}

Volcanic rocks of the Piskahegan Group occur along the western margin of the Maritimes Basin in southwestern New Brunswick (Fig. 1). The Maritimes Basin is a major late Paleozoic successor basin (Gibling et al., 2008) that was initiated after the Early to Middle Devonian Acadian Orogeny ( 400 Ma) in the Canadian Appalachians. This composite basin first developed as a series of pull-apart sub-basins along the Minas Fault Zone, a large east- trending dextral strike-slip system that juxtaposed the Meguma and Avalon terranes during the Late Devonian and the Carboniferous (Murphy et al., 2011a). Associated with these pull-apart structures are large bimodal plutons, as well as a series of NW-trending mafic dykes. Closely spaced $\mathrm{U}-\mathrm{Pb}$ dates for peak Acadian metamorphism and for the emplacement and exhumation of post-Acadian plutons along the Minas Fault Zone suggest that the transition from orogenic compression to transtension along this fault system was very rapid (Dostal et al., 2006). Also associated with this transtensional magmatic event are widely distributed bimodal volcanic suites, one of which is the Piskahegan Group. This group forms a volcanic caldera complex that is associated with a polymetallic deposit (Kooiman et al., 1986; McCutcheon et al., 1997; Thorne et al., 2013). The complex, referred to as the Mount Pleasant caldera, is a northeast-trending elliptical feature that is defined by geophysical data (regional gravimetric and magnetic studies) as about $13 \mathrm{~km}$ wide and $34 \mathrm{~km}$ long (McLeod and Smith, 2010). However, the northern part of the complex is overlain by middle Mississippian (Visean) and Pennsylvanian strata of the 
Maritimes Basin in such a way that the exposed length is restrained to about $17 \mathrm{~km}$. This epicontinental caldera, which was emplaced in a transtensional setting (Fyffe et al., 2011), is associated with high-level subvolcanic granitic intrusions and has been interpreted to have formed by roof collapse in an epizonal magma chamber. The Piskahegan Group (Figs. 1 and 2) disconformably overlies deformed Ordovician to Silurian turbiditic metasedimentary rocks of the Gander Terrane. These rocks bound the caldera to the east and west. The caldera is in turn paraconformably overlain by Visean clastic rocks formerly mapped as the Shin Redbeds by van de Poll (1967) and recently assigned the Shin Member of the Hopewell Cape Formation (Jutras et al., 2015), which confine the caldera to the north (Fig. 1). Late Silurian to Devonian granitic rocks of the Saint George Batholith represent the southern boundary of the complex (McLeod, 1990). Both the batholith and the caldera complex lie within the boundaries of the Gander Terrane.

The Piskahegan Group (Fig. 2) has been subdivided into three volcanic facies (in the sense of Fisher and Schmincke, 1984) in order to reflect their depositional setting in relation to the volcanic architecture: (1) exocaldera, (2) intracaldera and (3) late caldera-fill sequences (McCutcheon, 1990; McCutcheon et al., 1997; Thorne et al., 2013). The caldera is composed mainly of felsic volcanic and volcaniclastic rocks and associated sedimentary rocks, which are intruded by subvolcanic granitic bodies (McCutcheon et al., 1997). All three volcanic facies contain subordinate amounts of mafic and intermediate volcanic rocks (Fig. 2).

The Piskahegan Group was emplaced during the initial stages of basin development. Paleontological records and radiometric dating show that most of the caldera is Fammenian (Upper Devonian) in age and coincides with the emplacement of voluminous granitic intrusions. Anderson (1992) obtained a whole-rock Rb-Sr isochron age of $368 \pm 5$ Ma for the Piskahegan Group. The Carrow Formation (CF) of the exocaldera sequence yielded a U-Pb zircon age of $363.8 \pm 2.2 \mathrm{Ma}$ (Tucker et al., 1998), whereas a spore assemblage recovered from drill core above the zircon sample yielded a late Famennian age (McGregor and McCutcheon, 1988). More recently, Thorne et al. (2013) reported Re-Os ages of 369.7 $\pm 1.6 \mathrm{Ma}$ and $370.1 \pm 1.7 \mathrm{Ma}$ from molybdenite samples associated with W-Mo-Bi mineralization. There are also several ${ }^{40} \mathrm{Ar} /{ }^{39} \mathrm{Ar}$ ages of ca. $360 \mathrm{Ma}$ on the granitic rocks (Sinclair et al., 1988), and the youngest phase of the neighbouring Saint George Batholith, which is probably related to them, gave a U-Pb zircon age 
of $367 \pm 1 \mathrm{Ma}$ (Bevier 1988). Hence, all available data in the Piskahegan Group and associated plutonic rocks range within the Fammenian (sensu Richards, 2013).

The exocaldera sequence includes three units that also contain mafic or intermediate volcanic rocks. In ascending stratigraphic order, they are the Hoyt Station Basalt (HSB), the South Oromocto Andesite (SOA) and the Carrow Formation (CF). HSB is the basal unit of the exocaldera sequence (McCutcheon et al., 1997) and it consists mainly of a basalt flow unit that is about $20 \mathrm{~m}$ thick. The basalt is underlain by rhyolitic volcaniclastic rocks. The SOA unit is an up to $130 \mathrm{~m}$ thick succession of lava flows that is conformably overlain by the $\mathrm{CF}$. The latter is composed mainly of clastic sediments, but also contains an aphyric basalt flow $(<20 \mathrm{~m}$ thick $)$ near the top of the formation.

At the base, the intracaldera sequence includes the Scoullar Mountain Formation (SMF), which lies along the periphery of the caldera complex at the contact with pre-caldera rocks. This unit, the thickness of which ranges between 225 and $450 \mathrm{~m}$, is composed predominantly of clastic sedimentary rocks and interbedded andesitic lava flows and felsic volcaniclastic rocks. The upper part of the late caldera-fill sequence contains the Kleef Formation (KF), which consists of conglomeratic redbeds (40-75 m thick), basalts $(70-80 \mathrm{~m})$, and volcaniclastic rocks (> $4 \mathrm{~m})$.

The polymetallic deposit is located near the southwestern margin of the caldera complex (McCutcheon et al., 1997). It consists of mineralized stockworks and quartz veinlets, breccia infill and lode mineralization. Its formation is associated with the emplacement of the subvolcanic granitic rocks that host it. Thorne et al. (2013) inferred that the mineralization was associated with caldera collapse, which was marked by the emplacement of a series of subvolcanic granitic intrusions (Fig. 2 ).

\section{Analytical methods}

Mineral compositions (Table 1; Appendix 1) were determined using a JEOL Superprobe 733 equipped with four wave-length-dispersive spectrometers and one energy-dispersive spectrometer, and operated with a beam current of $15 \mathrm{kV}$ at $5 \mathrm{nA}$ at the Department of Earth Sciences of Dalhousie University, Halifax, Nova Scotia (Canada). 
Major and several trace element analyses of whole rocks (Table 2; Appendix 2) were performed on fused glass disks using a Philips PW2400 X-ray fluorescence spectrometer at the University of Ottawa, Ontario (Canada). Duplicate analyses of the samples yielded total errors of $\pm 3 \%(1 \sigma)$. Trace element analysis was done using lithium metaborate-tetraborate fusion and a Perkin Elmer Optima 3000 ICP mass spectrometer at Activation Laboratories, Ancaster, Ontario (Canada). Replicate analyses of the reference standard rocks indicate that the errors were between 2 and $8 \%$ of the values cited. The detection limits and other information on the trace element analyses (analytical package 4B2) are available at the Activation Laboratories web site (www.actlabs.com).

$\mathrm{Nd}$ isotope ratios (Table 3) were determined by isotope dilution mass spectrometry at the Department of Earth Sciences of the Memorial University of Newfoundland (St. John's, Newfoundland, Canada). Concentration data are standard ICP-MS analyses and are precise to $\pm 5 \%(2 \sigma)$. Ratios of ${ }^{147} \mathrm{Sm} /{ }^{144} \mathrm{Nd}$ (except samples 38A and 69) were measured directly by highprecision ICP-MS with an estimated precision of $\pm 0.5 \%(2 \sigma)$. The isotopic ratios of ${ }^{143} \mathrm{Nd} /{ }^{144} \mathrm{Nd}$ were determined using a multicollector Finnigan MAT 262V thermal ionization mass spectrometer operated in a static mode. Measured ${ }^{143} \mathrm{Nd} /{ }^{144} \mathrm{Nd}$ values were normalized to a ${ }^{146} \mathrm{Nd} /{ }^{144} \mathrm{Nd}$ ratio of 0.7219 . Replicate analyses of the LaJolla standard, which was analyzed repeatedly throughout, gave an average value for ${ }^{143} \mathrm{Nd} /{ }^{144} \mathrm{Nd}=0.511849 \pm 9$. The $2 \sigma$ values for all samples are less than or equal to 0.000008 for ${ }^{143} \mathrm{Nd} /{ }^{144} \mathrm{Nd}$ and are given in Table 3. Values for $\varepsilon_{\mathrm{Nd}(\mathrm{T})}$ were calculated with respect to CHUR using present-day ${ }^{143} \mathrm{Nd} /{ }^{144} \mathrm{Nd}$ and ${ }^{147} \mathrm{Sm} /{ }^{144} \mathrm{Nd}$ ratios of respectively 0.512638 and 0.196593 , and subsequently age-corrected. $\mathrm{A} \mathrm{T}_{\mathrm{DM} 1}$ model age was calculated using a linear evolution for a mantle that separated from CHUR at 4.55 Ga, and that has a present day $\varepsilon$ value of +10 . The $\mathrm{T}_{\mathrm{DM} 2}$ model age was calculated according to the model of DePaolo (1988).

\section{Petrography and mineral chemistry}

Basalts and andesites of the Piskahegan Group vary from massive to amygdaloidal. Amygdales occur particularly in the upper part of the flows and are commonly filled by carbonates or silica. Although rocks of the caldera are not significantly deformed and contain unstrained quartz with primary glass inclusions (Gray et al., 2011), the amygdaloidal rocks are 
altered. Igneous textures are mostly preserved, but the primary magmatic minerals are frequently replaced by secondary phases. The rocks exhibit greenschist grade metamorphism that produced chlorite, epidote and actinolite. Textures range from aphyric to coarse subophitic and ophitic, as well as porphyritic and glomeroporphyritic. The basalts are composed predominantly of plagioclase and clinopyroxene, which are variably altered and occur both as phenocrysts and as the main components of the groundmass. The rocks also contain minor Fe-Ti oxides and accessory apatite. No orthopyroxene was observed. When fresh, the plagioclase phenocrysts show zoning with labradorite-bytownite cores and andesine rims. However, plagioclase is mostly albitized or altered to sericite and calcite. Some plagioclase phenocrysts contain zones of sieve texture. The intermediate rocks contain relics of dark brownish-green amphibole replaced mainly by chlorite and epidote. In these rocks, subhedral amphibole crystallized together with plagioclase, Fe-Ti oxide, and apatite after the crystallization of clinopyroxene (Anderson, 1992). Amphibole may contain a core of clinopyroxene. The clinopyroxene phenocrysts show zoning, but are partially replaced by chlorite and epidote. Clinopyroxenes typically form subhedral phenocrysts and microphenocrysts or occur in a subophitic to ophitic groundmass of the mafic rocks. Relics of fresh clinopyroxene in the mafic and intermediate rocks are typically augite (Anderson, 1992; Table 1; Appendix 1). On tectonic discrimination diagrams for pyroxene (Leterrier et al., 1982), clinopyroxenes of the basalts plot in the "non-orogenic" field (Anderson, 1992; McCutcheon et al., 1997). Clinopyroxenes from the intermediate rocks (Table 1) also plot in the "non-orogenic" field (Fig. 3) of Leterrier et al. (1982). The rarity of phenocrysts in some samples of evolved rocks may be caused by the separation of early fractionated phases from the melt on the way to the surface.

\section{Whole-rock geochemistry}

\subsection{Alteration}

Alteration and metamorphic processes have affected the rocks. Petrographic evidence includes the saussuritization, sericitization, and albitization of feldspar, the chloritization of clinopyroxene as well as the accumulation of silica and calcite in amygdales. Although the original abundances of mobile elements such as $\mathrm{Ca}, \mathrm{Na}$ and $\mathrm{K}$ might have been modified, the concentrations and ratios of high-field strength elements (HFSE) and rare earth elements (REE) 
show well-defined trends indicating that these elements were immobile during alteration. This is also supported by many other studies (e.g., Winchester and Floyd, 1977) indicating that HFSE and REE retain their distribution during alteration. Furthermore, an investigation of melt inclusions in quartz of associated rhyolitic rocks (Gray et al., 2011) showed that post-magmatic processes did not modify the whole-rock composition. Similarly, it is typically inferred that the $\mathrm{Sm}$ and $\mathrm{Nd}$ isotope characteristics of a rock are resistant to geological disturbances (e.g., DePaolo, 1988).

\subsection{Major and trace elements}

All the major oxide compositions were recalculated to $100 \%$ on a volatile free basis for plotting on geochemical diagrams. According to their major element compositions (Fig. 4), the mafic and intermediate volcanic rocks of the Piskahegan Group can be subdivided into two associations: Association 1 includes basalts of the KF and $\mathrm{CF}$ formations, which are characterized by low $\mathrm{SiO}_{2}\left(48-52\right.$ wt.\%), and high $\mathrm{TiO}_{2}\left(>2.5\right.$ wt.\%) and $\mathrm{FeO}_{(\mathrm{t})}(\sim 13-15$ wt.\%), whereas Association 2 comprises intermediate rocks of the SOA and SMF, with $\mathrm{SiO}_{2}>54$ wt.\%, $\mathrm{TiO}_{2}<2$ wt.\%, and $\mathrm{FeO}_{(\mathrm{t})}<9$ wt.\% . The division is also shown in the $\mathrm{Zr} / \mathrm{TiO}_{2}$ versus $\mathrm{Nb} / \mathrm{Y}$ diagram (Fig. 5), in which Association 1 rocks plot in the basaltic field, whereas rocks of Association 2 plot mainly in the andesitic field.

According to the conventional AFM $\left[\left(\mathrm{K}_{2} \mathrm{O}+\mathrm{Na}_{2} \mathrm{O}\right)-\mathrm{FeO}_{(\mathrm{t})}-\mathrm{MgO}\right]$ diagram (Fig. 6), Association 1 rocks are tholeiites. They have characteristics of differentiated tholeiitic basalts with low $\mathrm{MgO}$, Ni and $\mathrm{Cr}$, as well as high $\mathrm{Fe}$, Ti and $\mathrm{P}$. Their chondrite-normalized REE patterns show a negative slope, resulting from an enrichment of light REE (LREE) with (La/Yb) $\sim 5-6$, but without $\mathrm{Eu}$ anomalies (Fig.7). The primitive mantle-normalized incompatible element plots of Association 1 rocks do not display noticeably negative Nb-Ta anomalies (Fig. 8). The patterns show distinct negative anomalies for $\mathrm{Ti}$ and $\mathrm{Sr}$, which together with low $\mathrm{Ni}$ and $\mathrm{Cr}$ indicate that the rocks underwent fractional crystallization dominated by plagioclase and clinopyroxene. Both patterns (Figs. 7 and 8) resemble those of rift-related continental tholeiites or transitional basalts (e.g., Dostal and Dupuy, 1984; Pegram, 1990; Dostal et al., 1992; Peate and Hawkesworth, 1996). In comparison with arc mafic rocks, the basalts have high Ti/V (70-100) and Zr/Y (6-8), and their primitive mantle-normalized trace element patterns do not exhibit pronounced negative 
Nb-Ta anomalies (Fig. 8). In addition, on geochemical discrimination diagrams, they plot in the field of rift-related basalts (Fig. 9).

Compared to those of Association 1, rocks of Association 2 have calc-alkaline characteristics (e.g., Fig. 6), although they were emplaced penecontemporaneously and in the same tectonic and geographic settings. With increasing $\mathrm{SiO}_{2}$, the andesites show a decrease in $\mathrm{Fe}, \mathrm{Ti}, \mathrm{Mg} \#\left(\mathrm{MgO} /\left[\mathrm{MgO}+\mathrm{FeO}_{(\mathrm{t})}\right]\right)$ and $\mathrm{Ni}$, but also an increase in alkalis and in the $\mathrm{Al}_{2} \mathrm{O}_{3} / \mathrm{CaO}$ and $\mathrm{La} / \mathrm{Yb}$ ratios (Fig. 4), indicating the crystallization of clinopyroxene, plagioclase and Fe-Ti oxide. The fractionation of Fe-Ti oxides, which is implied by a decrease of $\mathrm{FeO}_{(\mathrm{t})}, \mathrm{TiO}_{2}$, and $\mathrm{V}$ with increasing $\mathrm{SiO}_{2}$ in the calc-alkaline suite, suggests high $\mathrm{P}_{\mathrm{H} 2 \mathrm{O}}$ and $\mathrm{P}_{\mathrm{O} 2}$ conditions. The difference between tholeiitic and calc-alkaline suites can be partially due to the depth of fractional crystallization (e.g., Grove and Kinzler, 1986). Crystallization of the calc-alkaline magmas at mid-crustal depth may have differed from that of tholeiitic magma, which could have taken place at lower $\mathrm{P}_{\text {tot }}$ and lower $\mathrm{P}_{\mathrm{O} 2}$ conditions (i.e., within a shallow upper crustal magma chamber).

There are subtle differences between the SOA and SMF rocks. The SOA have $\mathrm{SiO}_{2} \sim 55-$ 58 wt. $\%, \mathrm{TiO}_{2}<2$ wt. $\%$ and $\mathrm{FeO}_{(\mathrm{t})} \sim 8 \mathrm{wt} . \%$. The $\mathrm{SMF}$ rocks are more fractionated, although there is some overlap in composition. They have typically higher $\mathrm{SiO}_{2}$ (59-66 wt.\%), lower $\mathrm{TiO}_{2}$ $<1.5$ wt.\% and lower $\mathrm{FeO}_{(\mathrm{t})}<8$ wt.\% (Table 2).

In addition to the differences in major element compositions between associations 1 and 2, the andesites have more fractionated REE patterns, with $(\mathrm{La} / \mathrm{Yb})_{\mathrm{n}} \sim 7-8.5$, but also without significant Eu anomalies. Their light REE (LREE) abundances are similar to those of the first association, but they have lower heavy REE (HREE) contents. The primitive mantle-normalized incompatible element plots of Association 2 show distinct negative $\mathrm{Nb}$-Ta anomalies, which are indicative of either subduction or crustal assimilation.

\subsection{Nd isotopic ratios}

The Sm-Nd isotopic signatures of the basaltic and andesitic rocks are given in Table 3, in which they are all age-corrected to $365 \mathrm{Ma}$. The $\varepsilon_{\mathrm{Nd}(\mathrm{T})}$ values of the basalts range from +2.5 to + 2.2 , and ${ }^{147} \mathrm{Sm} /{ }^{144} \mathrm{Nd}$ ratios vary from 0.13 to 0.14 (Table 3 ). The values are in good agreement with the data of Anderson (1992) for mafic rocks of the caldera. The data plot within the range 
reported for the Devonian to Carboniferous basaltic rocks of the Maritimes Basin in New Brunswick and Nova Scotia (Fig. 10). They are also similar to those from rift-related basalts, continental flood basalts and xenoliths from the subcontinental lithosphere (Faure and Mensing, 2005). These $\varepsilon_{\mathrm{Nd}(\mathrm{T})}$ values are considerably lower than values expected for juvenile magmas from a depleted mantle source (Fig. 10), although the positive $\varepsilon_{\mathrm{Nd}(\mathrm{T})}$ values preclude a significant contribution from substantially older continental crust or sedimentary rocks derived from it. The Piskahegan basaltic rocks plot in the field of Avalonian and peri-Rodinian lithosphere (Fig. 10), and their $\varepsilon_{\mathrm{Nd}(\mathrm{T})}$ values are consistent with derivation from a SCLM.

Neodymium depleted-mantle model ages of DePaolo (1988) for these rocks range between 800 and $900 \mathrm{Ma}$ (Table 3) and are similar to those determined for the Devonian to Carboniferous basaltic rocks above the Avalon and Gander terranes in the Maritimes Basin (Keppie et al., 1997; Pe-Piper and Piper, 1998). These similarities suggest that the model ages represent a bulk weighted average of the source composition.

The andesites have lower $\varepsilon_{\mathrm{Nd}(\mathrm{T})}$ than the basalts (Table 3), but they still plot in the field of Avalonian and Ganderian lithosphere (Fig. 10). The negative Nb-Ta anomalies and the lower $\varepsilon_{\mathrm{Nd}(\mathrm{T})}$ values $(+0.5$ to +1.9$)$ of these rocks are consistent with an inferred involvement of continental lithosphere in their evolution, most probably through crustal contamination.

\section{Discussion}

\section{1. Petrogenesis}

Although all volcanic rocks of the Piskahegan Group are spatially and temporarily associated, the Association 1 basalts are not related to the Association 2 andesites through simple crystal-liquid equilibria processes. The absence of smooth variation trends when various elements and element ratios are plotted against a differentiation index, such as $\mathrm{SiO}_{2}$ (Fig. 4), suggests that the Association 2 andesites did not simply result from the fractional crystallization of Association 1 basalts.

The Association 1 rocks are evolved tholeiites that were emplaced in an epicontinental rift-related setting. Compared to primitive basalts that have $\mathrm{Mg \#}$ values of $\sim 0.70$ (Hanson and Langmuir, 1978), the Piskahegan basalts (Table 2) have significantly lower values (0.34-0.40), suggesting that they have undergone high degrees of fractional crystallization. The fractional 
crystallization was dominated by crystallization of clinopyroxene and plagioclase. On the $\mathrm{Th} / \mathrm{Yb}$ versus $\mathrm{Nb} / \mathrm{Yb}$ diagram (Fig. 11), which has been used for the evaluation of lithospheric inputs in basalts (Pearce, 2008), the averages of N-type MORB, E-type MORB and OIB form a diagonal mantle array (Fig. 11). Magmas that were modified by an interaction with continental crust or that involved material with a subduction history are displaced to higher $\mathrm{Th} / \mathrm{Yb}$ values. The basaltic rocks of the Piskahegan Group straddle the boundary of the mantle array, implying that crustal contamination and subduction imprints were insignificant. This is also consistent with the lack of a discernible negative $\mathrm{Nb}$-Ta anomaly on the spider plots (Fig. 8). Thus, the composition of the basalts mostly reflects the original characteristics of the mantle source and, together with positive $\varepsilon_{\mathrm{Nd}(\mathrm{T})}$ values, indicate that they were derived from a relatively uncontaminated and moderately enriched mantle, similar to an ocean island basalt (OIB)-type source (Faure and Mensing, 2005).

On the $\mathrm{Tb} / \mathrm{Yb}$ versus La/Sm graph (Fig.12), the basaltic samples straddle the spinel peridotite-garnet peridotite boundary, suggesting that they were formed in a spinel-garnet transition zone, at a depth of $\sim 70-90 \mathrm{~km}$ (Wang et al., 2002). Whereas $\mathrm{Tb} / \mathrm{Yb}$ ratios are related to the pressure conditions and depth at which melting occurred, $\mathrm{La} / \mathrm{Sm}$ ratios correlate with the degree of partial melting and tend to decrease with an increase of mantle peridotite melting. Ratios for the CF and KF basalts are overlapping, which indicates that they were generated at the same depth by similar degrees of partial melting from a similar mantle source.

The andesites of the Piskahegan Group underwent fractional crystallization dominated by plagioclase, clinopyroxene and Fe-Ti oxide, as indicated by the variation trends of several elements and element ratios when plotted against $\mathrm{SiO}_{2}$ (Fig. 4). The compositional characteristics of the Association 2 rocks, including negative $\mathrm{Nb}$-Ta anomalies and their position on the $\mathrm{Th} / \mathrm{Yb}$ versus $\mathrm{Nb} / \mathrm{Yb}$ diagram (Fig. 11), suggest that the rocks record an additional process to fractional crystallization. The SOA and SMF andesites are displaced toward higher $\mathrm{Th} / \mathrm{Yb}$ ratios relative to the mantle array, implying crustal contamination or inputs from a subcontinental mantle that had previously been affected by subduction fluids.

Correlation of element and isotopic ratios suggests that the andesites were significantly changed by crustal contamination as discussed below. Trace element ratios, which are not modified by the fractional crystallization of major rock forming minerals and which have 
significantly different values for oceanic basalts (OIB, MORB) and continental crust (e.g., $\mathrm{Th} / \mathrm{La}, \mathrm{Th} / \mathrm{Nb}, \mathrm{Th} / \mathrm{Ta}, \mathrm{Nb} / \mathrm{U}$ ), are typically used as indicators for crustal contamination (e.g., Jochum et al., 1991; D’Antonio et al., 2007). The SOA andesites have higher Th/La ( 0.15$0.16), \mathrm{Th} / \mathrm{Nb}(0.3-0.45)$ and $\mathrm{Th} / \mathrm{Ta}(5-7)$ ratios than the basalts $(\mathrm{Th} / \mathrm{La} \sim 0.08-0.1, \mathrm{Th} / \mathrm{Nb} \sim 0.11-$ 0.19, and $\mathrm{Th} / \mathrm{Ta} \sim 1-3)$, indicating crustal input. The same applies for the SMF andesites, which have even higher $\mathrm{Th} / \mathrm{La}(\sim 0.20-0.25), \mathrm{Th} / \mathrm{Nb}(>0.5)$ and $\mathrm{Th} / \mathrm{Ta}(8-11)$ ratios. These ratios, which are sensitive indicators of crustal contamination, correlate with $\mathrm{SiO}_{2}$ (Fig. 4) and are consistent with an origin of the intermediate rocks by the crustal contamination of basalts accompanied by fractional crystallization. Such a process is also supported by mixing trends on the $\mathrm{Nb} / \mathrm{Th}$ versus $\mathrm{Th} / \mathrm{Yb}$ diagram (Fig. 13), in which the andesitic rocks plot along the mixing line between typical mantle-derived tholeiites and crustal material. A similar trend is also shown on Figure 9. Due to the absence of geochemical analyses from the underlying basement/continental crust, we have used the average continental crust composition of Taylor and McLennan (1985) as a reference contaminant for these graphs. Likewise, the plots involving $\mathrm{Nd}$ isotopes and contaminationsensitive trace element ratios or $\mathrm{SiO}_{2}$ suggest a mixing between the basaltic melts derived from the SCLM and crustal material. The rocks show a general trend of lower $\varepsilon_{\mathrm{Nd}(\mathrm{T})}$ with higher Th on the $\varepsilon_{\mathrm{Nd}(\mathrm{T})}$ versus Th/La graph (Fig. 14), confirming the involvement of continental crust in the rocks with lower $\varepsilon_{\mathrm{Nd}(\mathrm{T})}$.

The highly fractionated nature of the basalts as well as the observed gap between basalts and intermediate rocks indicate that the original magmas of each association had to undergo a separate evolution, although they may have had comparable parent magma. The Association 1 basalts underwent fractional crystallization during their rise to the surface, whereas the Association 2 andesites were modified by crustal contamination through assimilation-fractional crystallization (AFC) processes, probably at mid-crust levels. As the andesitic rocks contain hornblende indicative of mid-crust crystallization and show a calc-alkaline fractionation trend that is typical of high $\mathrm{P}_{(\text {tot })}$ and $\mathrm{P}_{\mathrm{H} 2 \mathrm{O}}$ conditions, the contamination had to take place at a deeper crustal level (e.g., Osborn, 1959; Zimmer et al., 2010). In addition to amphibole, the calcalkaline rocks also contain clinopyroxene phenocrysts, which, like those of the basalts, are typical of within plate, "non-orogenic" rocks (Fig. 3). The wet and/or oxidizing environment is also consistent with the lack of distinct negative Eu anomalies in most of the andesitic rocks 
(Fig. 7) which could be because the magmatic water content was high (Moore and Carmichael, 1998) and/or because the magmatic oxidation state was high, in which case most of the Eu would

have been present as $\mathrm{Eu}^{3+}$ and would not have been incorporated into the crystallizing plagioclase (e.g., Sisson and Grove, 1993).

Crustal contamination led to a change from a non-oxic environment, typical of tholeiitic rocks, to the oxidizing environment that is typical of calc-alkaline rocks (e.g., Osborn, 1959; Zimmer et al., 2010). In the case of the tholeiitic basalts, the original magma fractionated along a tholeiitic trend of "early iron" enrichment (non-oxic conditions). The magma which mixed with continental crust material followed a calc-alkaline fractionation trend of "no iron" enrichment (oxidizing conditions).

\subsection{Crustal contamination in a metallogenic province}

In the near vicinity of the Mount Pleasant caldera, there are several small Late Devonian plutons composed of Li-F-rich granites (e.g., Taylor, 1992; Whalen et al., 1996). These plutons as well as the Mount Pleasant complex are a part of a large tin belt described by Schuiling (1967) and Strong (1980), among others, which extends from North America to Europe. This belt, characterised by the occurrences of the mineralized Devono-Carboniferous Li-F- rich peraluminous leucogranites with broadly contemporaneous $\mathrm{S}-\mathrm{W}-(\mathrm{U})$ mineralization, can be followed along the late Paleozoic fold belts of the Canadian Appalachians and the Hercynian Orogen of western and central Europe, from New Brunswick (Mount Pleasant complex) and Nova Scotia (South Mountain Batholith at East Kemptville), to Newfoundland (Ackley Pluton), and across the Atlantic Ocean to southwestern England (Cornwall), France (Armorican Massif and Massif Central), Germany (Altenberg, Erzgebirge) and the Czech Republic (Zinnwald, Erzgebirge). The belt has a long mining history of Sn, W and $\mathrm{U}$ dating back to the Romans. Numerous studies (e.g., Dostal and Chatterjee, 1995; Haapala, 1997; Cuney et al., 2002; Dostal et al., 2004; Cerny et al., 2005) inferred that the magmatic and hydrothermal mineralizing events were essentially synchronous and that the uncommon chemical characteristics of the Li-F-rich leucogranites require an uncommon source material. It has been inferred that the parental magmas of the leucogranites, including those around the Mount Pleasant caldera, were derived from similar source reservoirs (Romer and Kroner, 2014), probably phlogopite/biotite-rich mid- 
crustal metasedimentary rocks (e.g., Dostal et al., 2004). Similar fluid-rich rocks could have acted as a crustal contaminant.

\section{3. Comparable rock suites and possible mantle sources}

Comparable Upper Devonian to Lower Carboniferous bimodal volcanic suites occur within the Maritimes Basin in Nova Scotia (western Cape Breton Island, Antigonish Highlands and Cobequid Highlands) and southern New Brunswick (e.g., Dostal et al., 1983; Keppie and

Dostal, 1980; Keppie et al., 1997; Pe-Piper and Piper, 1998). The basaltic rocks are rift-related, mainly fractionated continental tholeiites. In these basaltic rocks, $\varepsilon_{\mathrm{Nd}(\mathrm{T})}$ values are variable, ranging from +2.2 to +5.2 (Keppie et al., 1997; Pe-Piper and Piper, 1998). The basalts are considered to be derived from the SCLM (Pe-Piper and Piper, 1998).

To evaluate lithospheric mantle sources in the area, as well as the changes that they underwent during the Carboniferous, we have also determined the $\mathrm{Nd}$ isotopic ratios of the Carboniferous trachytes ( $335 \mathrm{Ma}$ old) from the Cumberland Hill Formation (Gander Terrane) of southern New Brunswick as these rocks are younger by about 30 M.y. than the bulk of the Devono-Carboniferous magmatism. These rocks were interpreted to be derived from an alkali basaltic magma by extensive fractional crystallization without being affected by crustal contamination (Gray et al., 2010). Such an origin is also in an agreement with their primitive mantle-normalized plots, in which the rocks do not show any negative $\mathrm{Nb}$-Ta anomalies (Gray et al., 2010). These rocks have higher $\varepsilon_{\mathrm{Nd}(\mathrm{T})}$ values $(+4.3$ to +3.3$)$ than the basaltic rocks of the Piskahegan Group, but have younger model ages ( 0.6 Ga; Table 3).

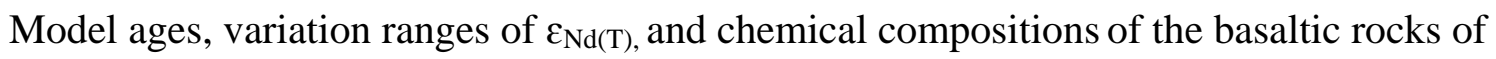
the Piskahegan Group, which are similar to those recorded in penecontemporaneous mafic lavas in both Avalonia and Ganderia, can be accounted for by derivation from a subcontinental lithospheric mantle that was locally modified by the upward invasion of enriched (OIB) asthenospheric magma (e.g., Pe-Piper and Piper, 1998). The basaltic magmas extruded due to rapid lithospheric thinning and an associated steepening of the geothermal gradient (e.g., Lynch and Tremblay, 1994; Pe-Piper and Piper, 1998). There does not appear to be a systematic difference between the Avalon and Gander terranes in the isotopic composition of the SCLM 
during the Late Devonian and the Early Carboniferous, and composition of the SCLM could therefore have been similar beneath both terranes in this part of the Appalachians.

\section{4. Possible link between mineralization and the development of a subordinate calc-alkaline suite}

The Upper Devonian to Lower Carboniferous rift-related volcanic suites that onlap the Avalon and Gander terranes along the margin of the Maritimes Basin are mostly bimodal continental tholeiite - rhyolite associations. The Piskahegan Group, which is associated with a significant polymetallic mineralization, differs from the rest of them by the presence of a significant amount of coeval calc-alkaline intermediate rocks. This calc-alkaline suite is interpreted to be the result of AFC processes involving the crustal contamination of a basaltic magma precursor, and of a change from non-oxic to oxidizing conditions accompanied by a relatively high content of magmatic water. The basalts also display an iron enrichment trend that is typical of low P shallow-seated fractionation that occurs in a non-oxic environment (Osborn, 1959; Zimmer et al., 2010). The calc-alkaline suite had a relatively high magmatic water content and/or high oxidation state, which are considered to be an indication of fertility for many polymetallic ore-bearing felsic and intermediate units (Candela, 1992; Richards, 2011). As rhyolites of the Piskahegan Group are also related to the andesitic rocks (Anderson, 1992; McCutcheon et al., 1997; Dostal et al., 2016b), it can be suggested that the evolution of these felsic rocks differed from those of other Upper Devonian to Lower Carboniferous bimodal volcanic suites. The presence of a significant amount of calc-alkaline volcanic rocks in such bimodal suites could be an indicator of potential mineralization.

\section{Conclusions}

Mafic and intermediate rocks of the Piskahegan Group constitute two distinct associations that are spatially and temporarily related within a Late Paleozoic caldera complex that hosts a significant polymetallic deposit of tin, tungsten, molybdenum, indium and bismuth. The first association includes basalts of the Kleef and Carrow formations, whereas the second association encompasses andesites of the South Oromocto Andesite and Scoullar Mountain formations. The basalts of the first association are fractionated, rift-related continental tholeiites 
with high contents of Fe, Ti, $\mathrm{P}$ and $\mathrm{V}$, but low $\mathrm{Mg}, \mathrm{Mg \#}$, Ni and $\mathrm{Cr}$. They display tholeiitic fractionation trends of $\mathrm{Fe}$ and $\mathrm{Ti}$ enrichment that are characteristic of dry and non-oxic environments. They underwent the main pulse of fractional crystallization at a relatively shallow depth, although the parent magma was generated in the transition zone between spinel and garnet peridotite at a depth of $\sim 70-90 \mathrm{~km}$. The mantle- normalized patterns of the basalts do not show distinct negative $\mathrm{Nb}$-Ta anomalies, and their geochemical characteristics mainly reflect a mantle source without noticeable signs of significant crustal contamination. Rocks of the second association display a typical calc-alkaline fractionation trend that is characterized by a gradual depletion of $\mathrm{Fe}$ and $\mathrm{Ti}$ with increasing differentiation, which is indicative of a wet and oxidizing environment. This is also consistent with the absence of a negative Eu anomaly in the REE patterns of these rocks, and with the presence of hornblende in their modal composition. The rocks resulted from the mixing of continental crust material (probably phlogopite/biotite-rich metasedimentary rocks) with primitive basaltic melt, likely at mid-crust level. Although the parent basaltic magmas of both suites could have been derived from the same SCLM source, they underwent separate and different evolution pathways. The Piskahegan Group, which is associated with the Mount Pleasant polymetallic deposit, differs from penecontemporaneous, non-mineralized bimodal suites that occur along the margins of the Maritimes Basin through New Brunswick and Nova Scotia by the presence of a significant amount of coeval calc-alkaline intermediate rocks. As such rocks evolve in water- and oxygen-rich magmatic environments, their presence may be considered to be an indicator of potential mineralization.

\section{Acknowledgements}

This study was supported by the New Brunswick Department of Energy and Mines, Geological Surveys Branch and the Natural Sciences and Engineering Research Council of Canada (Discovery grant to J.D.). We thank Malcom McLeod for the initiation of this project and Randy Corney for technical assistance. Constructive reviews by Drs. John Greenough, Nelson Eby and two anonymous referees improved the manuscript. 


\section{References}

Anderson, H.E. 1992. A chemical and isotopic study of the age, petrogenesis and magmatic evolution of the Mount Pleasant caldera complex, New Brunswick. Unpublished Ph.D. thesis, Carleton University, Ottawa, Ontario. 203 p.

Bevier, M.L., 1988. U-Pb geochronologic studies of igneous rocks in New Brunswick. In: Abbott, S.A. (Ed.) Thirteenth Annual Review of Activities, Project Résumés. New Brunswick Department of Natural Resources and Energy, Minerals and Energy Division, Information Circular 88-2, pp. 134-140.

Candela, P.A., 1992. Controls on ore metal ratios in granite-related ore systems: An experimental and computational approach. Transactions of the Royal Society of Edinburgh, Earth Sciences 83, 317-326.

Cerny, P., Blevin, P.L., Cuney M., London, D., 2005. Granite-related ore deposits. Economic Geology 100, 337-370.

Cuney, M., Alexandrov, P., LeCarlier de Veslud, C., Cheilletz, A., Raimbault, L., Ruffet, G., Scaillet S., 2002. The timing of W-Sn-rare metals mineral deposit formation in the Western Variscan chain in their orogenic setting: the case of the Limousin area (Massif Central, France). Geological Society of London Special Publication 204, 213-228.

D’Antonio, M., Tonarini, S., Arienzo, I., Covetta, L., Di Renzo, V., 2007. Components and processes in the magma genesis of the Phlegrean Volcanic District, southern Italy. Geological Society of America Special Papers 418, 203-220.

DePaolo, D.J., 1988. Neodymium Isotope Geochemistry: An Introduction. Springer Verlag, New York, $187 \mathrm{p}$.

Dostal, J., Dupuy, C., 1984. Geochemistry of the North Mountain basalts, Nova Scotia, Canada. Chemical Geology 45, 245-261.

Dostal, J., Chatterjee, A.K. 1995. Origin of topaz-bearing and related peraluminous granites of late Devonian Davis Lake pluton, Nova Scotia, Canada. Chemical Geology 123, 67-88.

Dostal, J., Chatterjee, A.K., Kontak, D.J. 2004. Chemical and isotopic (Pb, Sr) zonation in a peraluminous granite pluton: role of fluid fractionation. Contributions to Mineralogy and Petrology 147,74-90.

Dostal, J., Dupuy, C., Nicollet, C., Cantagrel, J.M., 1992. Geochemistry and petrogenesis of 
southern Malagasy. Chemical Geology 97, 199-218.

Dostal, J., Keppie, J. D., Dupuy, C., 1983. Petrology and geochemistry of Devono-Carboniferous volcanic rocks in Nova Scotia. Maritime Sediments and Atlantic Geology 19, 59-71.

Dostal, J., Keppie, J.D., Jutras, P., Miller, B.V., Murphy, J.B., 2006. Evidence of the granulitegranite connection: Penecontemporaneous high-grade metamorphism, granitic magmatism and core complex development in the Liscomb Complex, Nova Scotia, Canada. Lithos 86, 77-90.

Dostal, J., Keppie, J.D., Wilson, R. A., 2016a. Nd isotopic and trace element constraints on the source of Silurian-Devonian mafic lavas in the Chaleur Bay Synclinorium of New Brunswick (Canada): Tectonic implications. Tectonophysics 681, 364-375.

Dostal, J., van Hengstum, T.R., Shellnutt, J.G., Hanley, J.J. 2016b. Petrogenetic evolution of Late Paleozoic rhyolites of the Harvey Group, southwestern New Brunswick (Canada) hosting uranium mineralization. Contributions to Mineralogy and Petrology 171: DOI 10.1007/s00410-016-1270-8.

Faure, G., Mensing, T. M., 2005. Isotopes: Principles and Applications. John Wiley and Sons, Hoboken, New Jersey, 3rd edition, 897 p.

Fisher, R.V., Schmincke, H.U., 1984. Pyroclastic rocks. Springer-Verlag, New York, 472 p. Fyffe, L.R., Johnson, S.C., van Staal, C.R., 2011. A review of Proterozoic to Early Paleozoic lithotectonic terranes in the northeastern Appalachian orogen of New Brunswick, Canada, and their tectonic evolution during Penobscot,Taconic, Salinic, and Acadian orogenesis. Atlantic Geology 47, 211-248.

Gibling, M.R., Culshaw, N., Rygel, M.C., Pascucci, V., 2008. The Maritimes Basin of Atlantic Canada: Basin Creation and Destruction in the Collisional Zone of Pangea. In: Miall, A.D. (Ed.) Sedimentary Basins of the World, Vol. 5, pp. 211-244. Elsevier, Amsterdam. Gray, T.R., Dostal, J., McLeod, M., Keppie, J.D., Zhang, Y.Y., 2010. Geochemistry of Late Paleozoic peralkaline felsic volcanic rocks, central New Brunswick. Atlantic Geology 46, 173-184.

Gray, T.R., Hanley, J.J., Dostal, J., Guillong, M., 2011. Magmatic enrichment of uranium, thorium and rare earth elements in late Paleozoic rhyolites of southern New Brunswick, Canada: evidence from silicate melt inclusions. Economic Geology 106, 127-143. 
Grove, T.L., Kinzler, R.J., 1986. Petrogenesis of andesites. Annual Review of Earth and Planetary Sciences 14, 417-454.

Haapala, I., 1997. Magmatic and postmagmatic processes in tin mineralized granites: topazbearing leucogranite in the Eurajoki Rapakivi granite stock, Finland. Journal of Petrology 38, 1645-1659.

Hanson, G.N., Langmuir, C.H., 1978. Modelling of major elements in mantle-melt systems using trace element approaches. Geochimica et Cosmochimica Acta 42, 725 -742.

Irvine, T. N., Baragar, W. R. A., 1971. A guide to the chemical classification of the common volcanic rocks. Canadian Journal of Earth Sciences 8, 523-548.

Jochum, K.P., Arndt, N.T., Hofmann, A.W., 1991. Nb-Th-La in komatiites and basalts: constraints on komatiite petrogenesis and mantle evolution. Earth and Planetary Science Letters 107, 272-291.

Jutras, P., McLeod, J., MacRae, R.A., Utting, J., 2015. Complex, interplay of faulting, glacioeustatic variations and halokinesis during deposition of upper Visean units over thick salt in the western Cumberland Basin of Atlantic Canada. Basin Research 2015, 1-24.

Keppie, J. D., Dostal, J., 1980. Palaeozoic volcanic rocks of Nova Scotia. International Geological Correlation Programme Project 27: Caledonide Orogen. Proceedings of Virginia Polytechnic Institute and State University Memoir 2, 249-256.

Keppie, J. D., Dostal, J., Murphy, J. B., Cousens, B. L., 1997. Palaeozoic within-plate volcanic rocks in Nova Scotia (Canada) reinterpretation: isotopic constraints on magmatic source and palaeocontinental reconstructions. Geological Magazine 134, 425-447.

Keppie, J.D., Murphy, J.B., Nance, R.D., Dostal, J., 2012. Mesoproterozoic Oaxaquia-type basement in peri-Gondwanan terranes of Mexico, the Appalachians and Europe: TDM age constraints on extent and significance. International Geology Review 54, 313-324.

Kooiman, G.J.A., McLeod, M.J., Sinclair, W.D., 1986. Porphyry tungsten-molybdenum ore bodies, polymetallic veins and replacement bodies, and tin-bearing greisen zones in the Fire Tower Zone, Mount Pleasant, New Brunswick. Economic Geology 81, 1356-1373.

Leterrier, J., Maury, R.C., Thoron, P., Girard, D., Marchal, M., 1982. Clinopyroxene composition as a method of identification of the magmatic affinities of paleo-volcanic series. Earth and Planetary Science Letters 59, 139-154. 
Linnen, R.L., Cuney, M., 2005. Granite-related rare-element deposits and experimental constraints on Ta-Nb-W-Sn-Zr-Hf mineralization. In: Linnen, R.L., Samson, I.M. (Eds.) Rare-element geochemistry and mineral deposits: Geological Association of Canada Short Course Notes, v. 17, p. 45-68.

Lynch, G., Tremblay, C., 1994. Late Devonian-Carboniferous detachment faulting and extensional tectonics in western Cape Breton Island, Nova Scotia, Canada. Tectonophysics $238,55-69$.

McCutcheon, S.R., 1990. The Late Devonian Mount Pleasant Caldera complex stratigraphy, mineralogy, geochemistry and geological setting of a Sn-W deposit in southwestern New Brunswick. Unpublished Ph.D. thesis, Dalhousie University, Halifax, Nova Scotia, 609 p.

McCutcheon, S.R., Anderson, H.E., Robinson, P.T., 1997. Stratigraphy and eruptive history of the Late Devonian Mount Pleasant Caldera Complex, Canadian Appalachians. Geological Magazine 134, 17-36.

McCutcheon, S.R., Sinclair, W.D., McLeod, M.J., Boyd, T., Kooiman, G.J.A., 2010. Mount Pleasant Sn-W-Mo-Bi-In deposit. In: Fyffe, L.R., Thorne, K.G. (Eds.) Polymetallic Deposits of Sisson Brook and Mount Pleasant, New Brunswick, Canada. New Brunswick Department of Natural Resources; Lands, Minerals and Petroleum Division, Field Guide No. 3, p. 37-68.

McGregor, D.C., McCutcheon, S.R. 1988. Implications of spore evidence for Late Devonian age of the Piskahegan Group, southwestern New Brunswick. Canadian Journal of Earth Sciences 25, 1349-1364.

McLeod, M.J., 1990. Geology, Geochemistry, and Related Mineral Deposits of the Saint George Batholith; Charlotte, Queens, and Kings Counties, New Brunswick. New Brunswick Department of Natural Resources and Energy, Mineral Resources, Mineral Resource Report $5,169 \mathrm{p}$.

McLeod, M. J., Smith, E.A., 2010. Uranium. New Brunswick Department of Natural Resources; Lands, Minerals and Petroleum Division, Mineral Commodity Profile No. 6, 7 p.

Moore, G.M., Carmichael, I.S.E., 1998. The hydrous phase equilibria (to $3 \mathrm{kbar}$ ) of an andesite and basaltic andesite from western Mexico: constraints on water content and conditions of phenocryst growth. Contributions to Mineralogy and Petrology 130, 304-319.

Murphy, J.B., Dostal, J., Keppie, J.D., 2008. Neoproterozoic-Early Devonian magmatism 
in the Antigonish Highlands, Avalon terrane, Nova Scotia: tracking the evolution of the mantle and crustal sources during the evolution of the Rheic Ocean. Tectonophysics 461, 181-201.

Murphy, J.B., Waldron, J.W.F, Kontak, D.J., Pe-Piper, G.P., Piper, D. J.W., 2011a. Minas fault zone; late Paleozoic history of an intra-continental orogenic transform fault in the Canadian Appalachians. Journal of Structural Geology 33, 312-328.

Murphy, J.B., Dostal, J., Gutierrez-Alonso, G., Keppie, J.D., 2011b. Early Jurassic magmatism on the northern margin of CAMP: derivation from a Proterozoic sub-continental lithospheric mantle. Lithos 123, 158-164.

Nekvasil, H., Simon, A., Lindsley, D. H., 2000. Crystal fractionation and the evolution of intraplate hy-normative igneous suites: insights from their feldspars. Journal of Petrology 41, 1743-1757.

Osborn, E. F., 1959. Role of oxygen pressure in the crystallization and differentiation of basaltic magma. American Journal of Science 257, 609-647.

Pe-Piper, G., Piper, D.J.W., 1998. Geochemical evolution of Devonian-Carboniferous igneous rocks of the Maritimes Basin, Eastern Canada: $\mathrm{Pb}$-and $\mathrm{Nd}$-isotope evidence for mantle and lower crustal sources. Canadian Journal of Earth Science 35, 201-221.

Pearce, J.A., 2008. Geochemical fingerprinting of oceanic basalts with applications to ophiolite classification and the search for Archean oceanic crust. Lithos 100, 14-48.

Peate, D.W., Hawkesworth, C.J., 1996. Lithosphere to asthenosphere transition in low-Ti from southern Paraná, Brazil. Chemical Geology 127, 1-24.

Pegram, W.J., 1990. Development of continental lithospheric mantle as reflected in the Appalachian tholeiites. Earth and Planetary Science Letters 97, 316-331.

Richards, B.C., 2013. Current status of the International Carboniferous Time Scale. In: Lucas, S. G., et al., (Eds.) The Carboniferous-Permian Transition. New Mexico Museum of Natural History and Science, Bulletin 60, 348-353.

Richards, J.P., 2011. High Sr/Y magmas and porphyry $\mathrm{Cu} \pm \mathrm{Mo} \pm$ Au deposits: Just add water. Economic Geology 106, 1075-1081.

Richardson, D.G., Birkett, T.C., 1996. Peralkaline rock-associated rare metals. In: The Geology of North America, Geological Society of America, v. P-1, p. 523-540. 
Romer, R.L., Kroner, U., 2014. Magmatic tin-tungsten deposits within the Acadian-VariscanAlleghanian orogen: from the Gondwana source to the mineralization. Gondwana 15 Conference, Madrid, Abstract Book, p. 151.

Schuiling, R. D., 1967. Tin belts on the continents around the Atlantic Ocean. Economic Geology 62, 540-550.

Sinclair, W.D., Kooiman, G.J.A., Martin, D.A., 1988. Geological setting of granites and related tin deposits in the North Zone, Mount Pleasant, New Brunswick. In: Current Research, Part B, Geological Survey of Canada, Paper 88-1B, 201-208.

Sinclair, W.D., Kooiman, G.J.A., Martin, D.A., Kjarsgaard, I.M., 2006. Geology, geochemistry and mineralogy of indium resources at Mount Pleasant, New Brunswick, Canada. Ore Geology Reviews 28, 123-145.

Sisson, T.W., Grove, T.L., 1993. Experimental investigations of the role of $\mathrm{H}_{2} \mathrm{O}$ in calc-alkaline differentiation and subduction zone magmatism. Contributions to Mineralogy and Petrology 113, 143-166.

Smith, E., 2006. Bedrock geology of southwestern New Brunswick (NTS 21 g, part of 21 B). New Brunswick Department of Natural Resources, Minerals, Policy and Planning Division, Plate NR-5 2nd edition, scale 1:250 000.

Smith, E., Fyffe, L.R., 2006. Bedrock geology of central New Brunswick (NTS 21J). New Brunswick Department of Natural Resources, Minerals, Policy, and Planning Division, Plate NR-4 2nd edition, scale 1: 250000.

Strong, D.F., 1980. Granitoid rocks and associated mineral deposits of eastern Canada and western Europe. In: Strangway, D. W. (Ed.) The Continental Crust and its Mineral Deposits. Geological Association of Canada Special Paper 20, 742-769.

Sun, S. S., McDonough, W. F., 1989. Chemical and isotopic systematics of oceanic basalts: implications for mantle composition and processes. In: Saunders, A.D., Norry, M.J. (Eds.) Magmatism in the Ocean Basins: Geological Society London Special Publication 42, 313345.

Taylor, R.P., 1992. Petrological and geochemical characteristics of the Pleasant Ridge zinwaldite-topaz granite, southern New Brunswick, and comparison with other topazbearing felsic rocks. Canadian Mineralogist 30, 895-921. 
Taylor, S.R., McLennan, S.M., 1985. The continental crust: Its composition and evolution: An examination of the geochemical record preserved in sedimentary rocks. Blackwell Scientific, Oxford, United Kingdom, 312 p.

Thorne, K. G., Fyffe, L.R. Creaser, R.A., 2013. Re-Os geochronological constraints on the mineralizing events within the Mount Pleasant Caldera: implications for the timing of subvolcanic magmatism. Atlantic Geology 49, 131-150.

Tucker, R.D., Bradley, D.C., Ver Straeten, C.A., Harris, A.G., Ebert, J.R., McCutcheon, S.R., 1998. New U-Pb zircon ages and the duration and division of Devonian time. Earth and Planetary Science Letters 158, 175-186.

van de Poll, H. W., 1967. Carboniferous volcanic and sedimentary rocks of the Mount Pleasant area, New Brunswick. New Brunswick Department of Natural Resources and Energy, Mineral Resources Branch, Report of Investigations 3, 52 pp.

van Staal, C.R., Barr, S.M., 2012. Lithospheric architecture and tectonic evolution of the Canadian Appalachians and associated Atlantic margin. Chapter 2. In: Percival, J.A., Cook, F.A., Clowes, R.M. (Eds.), Tectonic Styles in Canada: the LITHOPROBE Perspective. Geological Association of Canada Special Paper 49, 41-95.

Wang, K., Plank, T., Walker, J.D., Smith, E.I., 2002. A mantle melting profile across the Basin and Range. SW USA. Journal of Geophysical Research 107(B1): ECV 5-1-ECV 5-21.

Whalen J.B., Fyffe, L.R., Longstaffe, F.J., Jenner, G.A., 1996. The position and nature of the Gander-Avalon boundary, southern New Brunswick, based on geochemical and isotopic data from granitoid rocks. Canadian Journal of Earth Sciences 33, 129-139.

Winchester, J.A., Floyd, P.A., 1977. Geochemical discrimination of different magma series and their differentiation products using immobile elements. Chemical Geology 20, 325-343.

Wood, D. A., 1980. The application of a Th-Hf-Ta diagram to problems of tectomagmatic classification and to establishing the nature of crustal contamination of basaltic lavas of the British Tertiary Volcanic Province. Earth and Planetary Science Letters 50, 11-30, Zimmer, M.M., Plank, T., Hauri, E.H., Yogodzinski, G.M., Steeling, P., Larsen, J., Singer, B., Jicha, B., Mandeville, C., Nye, C., 2010. The role of water in generating the calc-alkaline trend: new volatile data for Aleutian magmas and a new tholeiitic index. Journal of Petrology 51, 2411-2444. 


\section{Captions to Figures}

Figure 1. A - Map of a part of Atlantic Canada that shows the western boundary of the Maritimes Basin and the location of the Harvey and Piskahegan groups (black fields). B - Simplified geological map of the southwestern part of the Marysville sub-basin and its surroundings (modified from Smith, 2006, and Smith and Fyffe, 2006) showing the location of Figure 2. The insert (map of Canada) shows the location of Figure 1A. The Harvey Group is assumed to be an extension of the Mount Pleasant complex.

Figure 2. Geology of the Mount Pleasant Caldera Complex and its surroundings (modified from McCutcheon et al. 2010, and Thorne et al., 2013). Late Devonian caldera complex includes Late caldera-fill sequence, Subvolcanic intrusive rocks, Intracaldera and Exocaldera sequences while the Piskahegan Group encompasses Late caldera-fill, Intracaldera and Exocaldera sequences.

Figure 3. $(\mathrm{Ti}+\mathrm{Cr}$ ) versus $\mathrm{Ca}$ (number of cations per six oxygens) discrimination diagram of Leterrier et al. (1982) comparing the composition of clinopyroxenes from the intermediate rocks of the Piskahegan Group with compositional fields for clinopyroxenes from nonorogenic and orogenic rocks. Each value (Table 1) is an average composition of a number of analyzed crystals, and composition of each crystal is an average of 4 analyses (Table 1).

Figure 4. Variations of $\mathrm{FeO}^{*}$ (total $\mathrm{Fe}$ as $\mathrm{FeO}$ ), $\mathrm{TiO}_{2}$ (wt.\%) and various element ratios versus $\mathrm{SiO}_{2}$ (wt.\%) in the basaltic and andesitic rocks of the Piskahegan Group. Association 1 basalt: Carrow Formation (CF), Kleef Formation (KF); Association 2 - andesite: South Oromocto Andesite Formation (SOA); Scoullar Mountain Formation (SMF). In A and B, the vectors show calc-alkaline and tholeiitic trends whereas $\mathrm{E}$ and $\mathrm{F}$ show vectors for crustal contamination (cc) and fractional crystallization (fc).

Figure 5. $\mathrm{Zr} / \mathrm{TiO}_{2}$ versus $\mathrm{Nb} / \mathrm{Y}$ discrimination diagram of Winchester and Floyd (1977) for mafic and intermediate rocks of the Piskahegan Group. Alk-Bas - alkali basalt; TrachAnd trachyandesite. Association 1 - basalt: Carrow Formation (CF), Kleef Formation (KF); Association 2 - andesite: South Oromocto Andesite (SOA); Scoullar Mountain Formation (SMF). 
Figure 6. AFM diagram $\left(\mathrm{A}=\left[\mathrm{Na}_{2} \mathrm{O}+\mathrm{K}_{2} \mathrm{O}\right], \mathrm{F}=\right.$ total $\mathrm{Fe}$ as $\left.\mathrm{FeO}, \mathrm{M}=\mathrm{MgO}\right)$ for analyzed mafic and intermediate volcanic rocks from the Piskahegan Group. The solid line is the boundary between tholeiitic and calc-alkaline fields after Irvine and Baragar (1971); Association 1 (basalts): Carrow Formation (CF), Kleef Formation (KF); Association 2 (andesites): South Oromocto Andesites (SOA), Scoullar Mountain Formation (SMF).

Figure 7. Chondrite-normalized REE patterns for basaltic and andesitic rocks of the Piskahegan Group. A- Range of basalts from the Carrow Formation; B - Range of basalts from the Kleef Formation; C - Range of andesites from the South Oromocto Andesite Formation; D - Range of andesites from the Scoullar Mountain Formation. Normalizing values are after Sun and McDonough (1989).

Figure 8. Primitive mantle-normalized multielement patterns in basaltic and andesitic rocks of the Piskahegan Group. A - Basalts of the Carrow Formation; B - Basalts of the Kleef Formation; C- Andesites of the South Oromocto Andesite Formation; D- Andesites of the Scoullar Mountain Formation. Normalizing values are after Sun and McDonough (1989).

Figure 9. Th-Hf-Ta tectonic discrimination diagram of Wood (1980) for mafic and intermediate volcanic rocks of the Piskahegan Group. Fields: N-MORB - normal, depleted mid-ocean ridge basalt; E-MORB/WPT - enriched mid-ocean ridge basalt and within-plate tholeiite; Alk WPB - alkaline within-plate basalt; CAB - calc-alkaline volcanic arc basalt; ATB volcanic arc tholeiite; CC (star) - average continental crust composition of Taylor and McLennan (1985). Note that the trend of the Piskahegan rocks is suggestive of a mixing between basaltic magma and crustal material.

Figure 10. $\varepsilon_{\mathrm{Nd}(\mathrm{t})}$ versus time plot comparing Sm-Nd isotopic data of the Piskahegan basalts and andesites and the Carboniferous Cumberland Hill trachytes with a compilation of Sm-Nd isotopic data for the Upper Devonian-Lower Carboniferous volcanic rocks of the Maritimes Basin and the Avalon Terrane (Keppie et al., 1997, Pe-Piper and Piper, 1998). The shaded area is the Avalonian basement and the SCLM (after Murphy et al., 2011b, Dostal et al., 2016a). The field for Mesoproterozoic rocks is from Murphy et al. (2008). Bars show a range of samples.

Figure 11. Th/Yb versus $\mathrm{Nb} / \mathrm{Yb}$ diagram of Pearce (2008) for Piskahegan basalts and andesites. Vectors indicate the influence of a subduction component (S), within-plate enrichment (W), 
crustal contamination (C), and fractional crystallization (FC); N-MORB- N-type mid-ocean ridge basalt; E-MORB- enriched mid-ocean ridge basalt; OIB-ocean island basalt (after Sun and McDonough, 1989). The star (CC) is the average of continental crust (Taylor and McLennan, 1985).

Figure 12. $(\mathrm{Tb} / \mathrm{Yb})_{\mathrm{n}}$ versus $(\mathrm{La} / \mathrm{Sm})_{\mathrm{n}}$ diagram for the Piskahegan basalts and andesites. The values are normalized to the primitive mantle after Sun and McDonough (1989). The solid line separating the range of magmas formed by the melting of spinel peridotite mantle from that of magmas formed by the melting of garnet peridotite mantle is after Wang et al. (2002). Vector D indicates an increase of melting depth whereas the vector $M$ depicts an increase in the degree of partial melting. The limited range of $(\mathrm{Tb} / \mathrm{Yb})_{\mathrm{n}}$ values for the basalts indicates a similar mantle source. The higher $(\mathrm{La} / \mathrm{Sm})_{\mathrm{n}}$ ratios of the calc-alkaline rocks is more suggestive of crustal contamination than of changes in the magma source region. The EMORB (enriched mid-ocean ridge basalt) and OIB (ocean island basalt) are after Sun and McDonough (1989).

Figure 13. $(\mathrm{Nb} / \mathrm{Th})_{\mathrm{n}}$ versus $(\mathrm{Th} / \mathrm{Yb})_{\mathrm{n}}$ diagram for the Piskahegan basalts and andesites. The ratios are normalized to the primitive mantle values of Sun and McDonough (1989). N-MORB and E-MORB compositions are from Sun and McDonough (1989). CC (star) - average continental crust (Taylor and McLennan, 1985). Note that the distinct trend (the solid curve is a mixing curve) of the Piskahegan rocks is suggestive of a mixing between parental basaltic magmas and crustal material, indicating that the andesitic magma assimilated significant amounts of crustal material prior to its emplacement.

Figure 14. Th/La versus $\varepsilon_{\mathrm{Nd}(\mathrm{T})}$ plot for the Piskahegan basalts and andesites. An increase of the $\mathrm{Th} / \mathrm{La}$ ratio accompanied by a decrease of $\varepsilon_{\mathrm{Nd}(\mathrm{T})}$ is indicative of a crustal contamination of the basaltic magmas. CC (star) - average continental crust composition (Taylor and McLennan, 1985). The solid triangles are data from Anderson (1992) for the Piskahegan basaltic and andesitic rocks. 


\section{Tables}

Table 1. Chemical composition and structural formulas of clinopyroxene in andesites of the Piskahegan Group

Table 2. Major and trace element compositions in the mafic and intermediate rocks of the Piskahegan Group

Table 3. Sm-Nd isotopic data for volcanic rocks of the Piskahegan Group and Cumberland Hill Formation

Appendix 1. Compostion of clinopyroxenes from andesites of the Piskahegan Group Appendix 2. Major and trace element compositions of andesitic rocks of the Piskahegan Group 


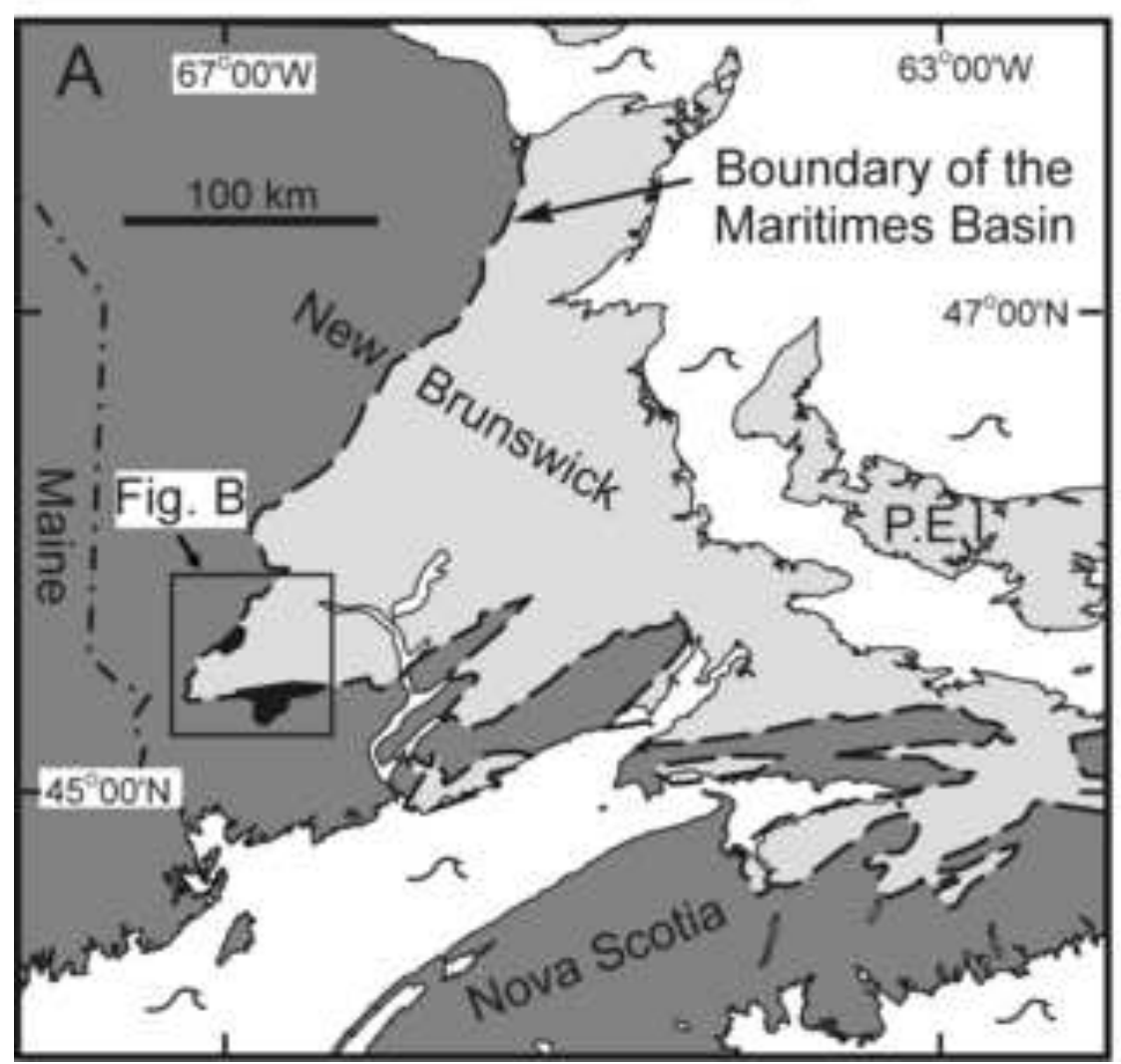

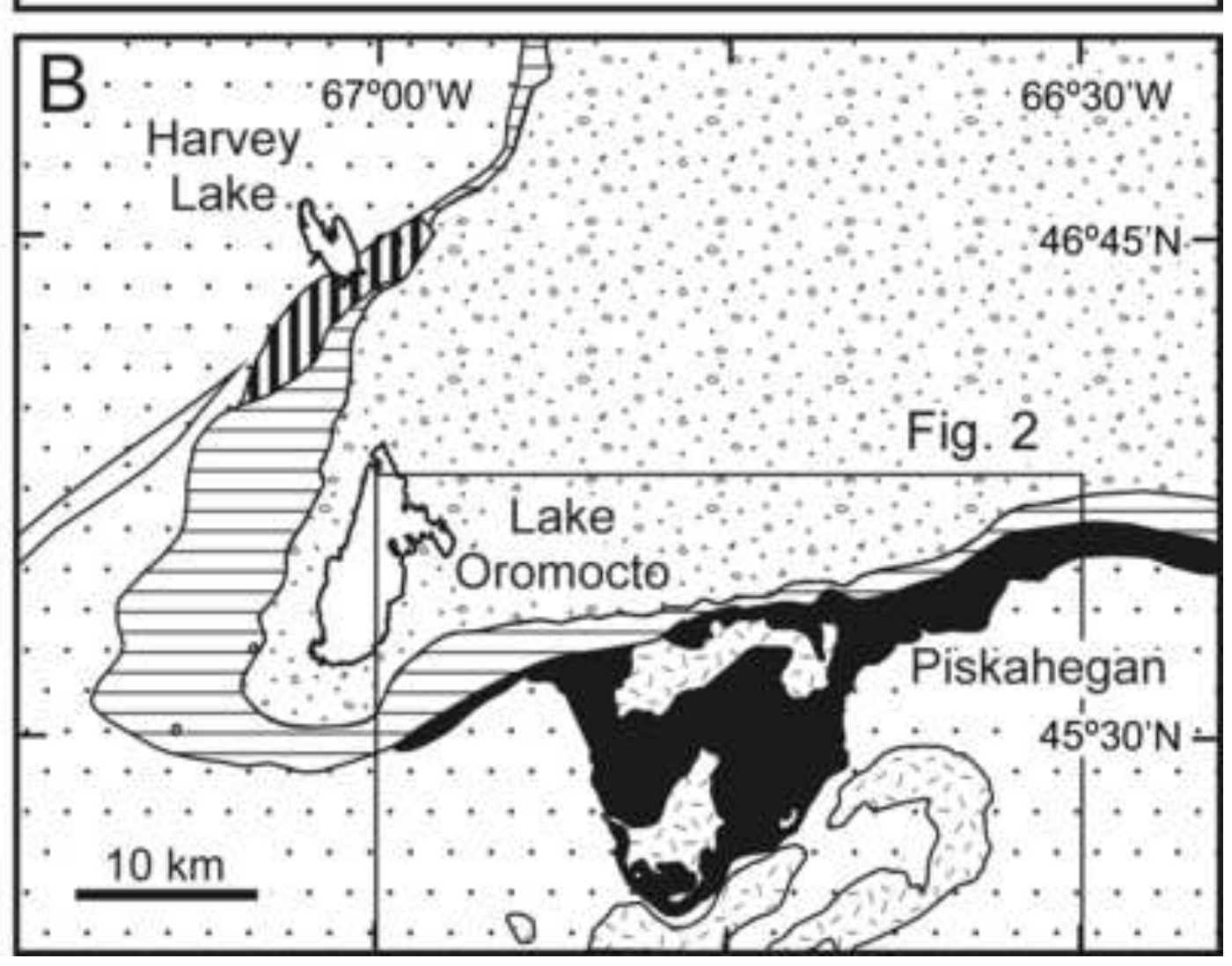

Granitic rocks $\checkmark$ fault

\section{$\because$ Silurian sedimentary \\ $\because$ Silurian sedimentary}

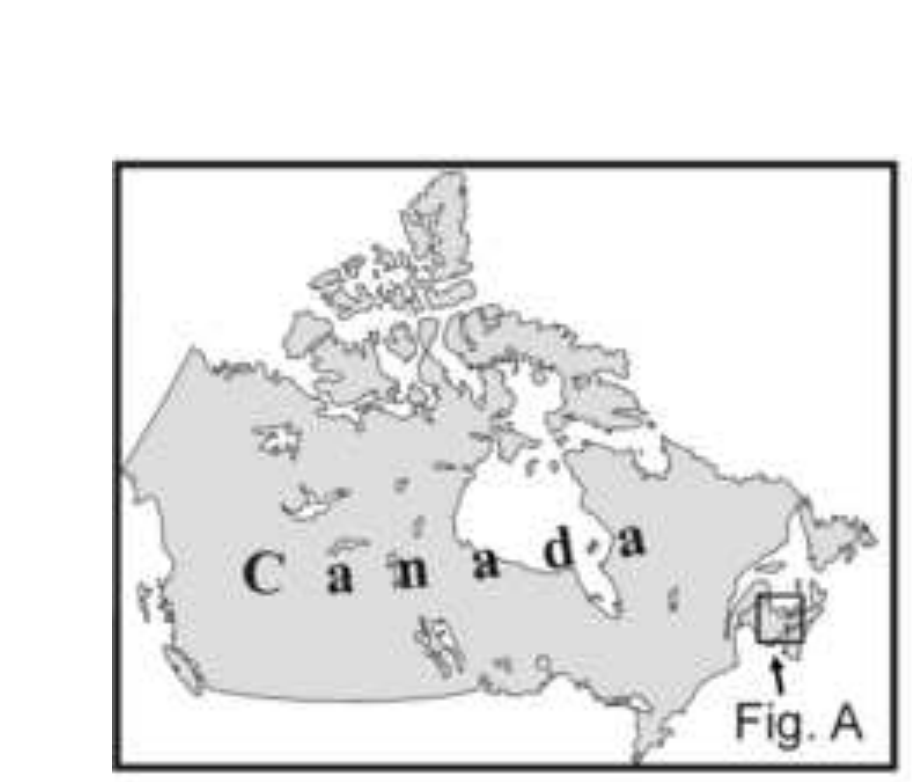

$\square$ Hopewell Cape (Shin)

Formation

Pictou Group

Piskahegan Group

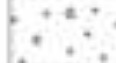

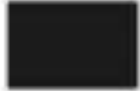

[IIII Harvey Group 


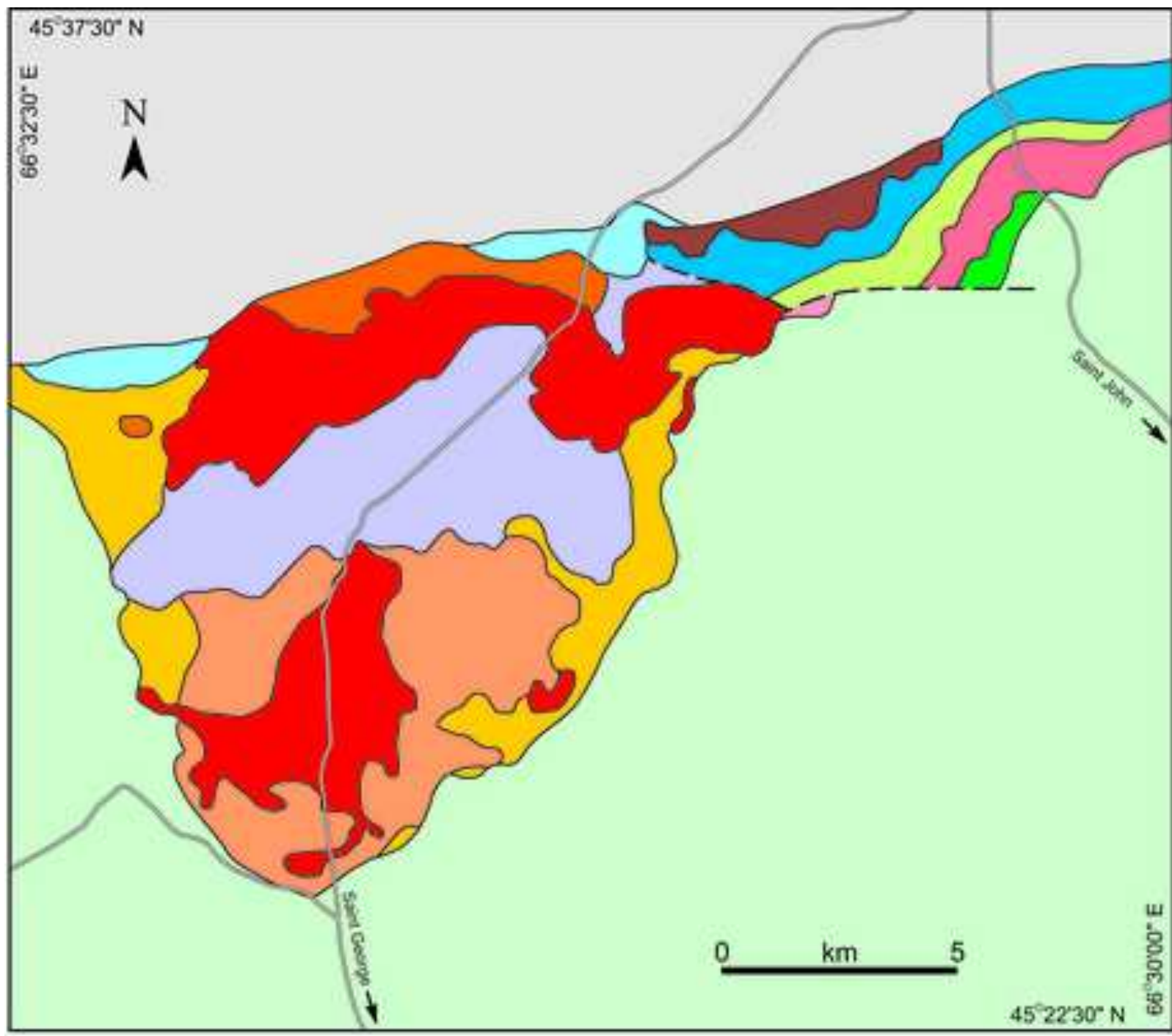

CARBONIFEROUS

sedimentary rocks

\section{LATE DEVONIAN}

Late Caldera - Fill Sequence

Kleef Formation

Big Scott Mountain Formation

Subvolcanic Intrusive Rocks

McDougall Brook Granite Suite

Intracaldera Sequence

Seelys Formation

Little Mount Pleasant Formation

Scoullar Mountain Formation

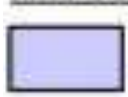

Exocaldera Sequence

Bailey Rock Rhyolite

Carrow Formation

South Oromocto Andesite

Rothea Formation

Hoyt Station Basalt

ORDOVICIAN - LATE SILURIAN

Pre-caldera rocks 


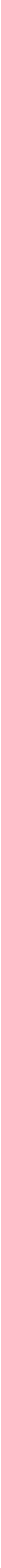

.




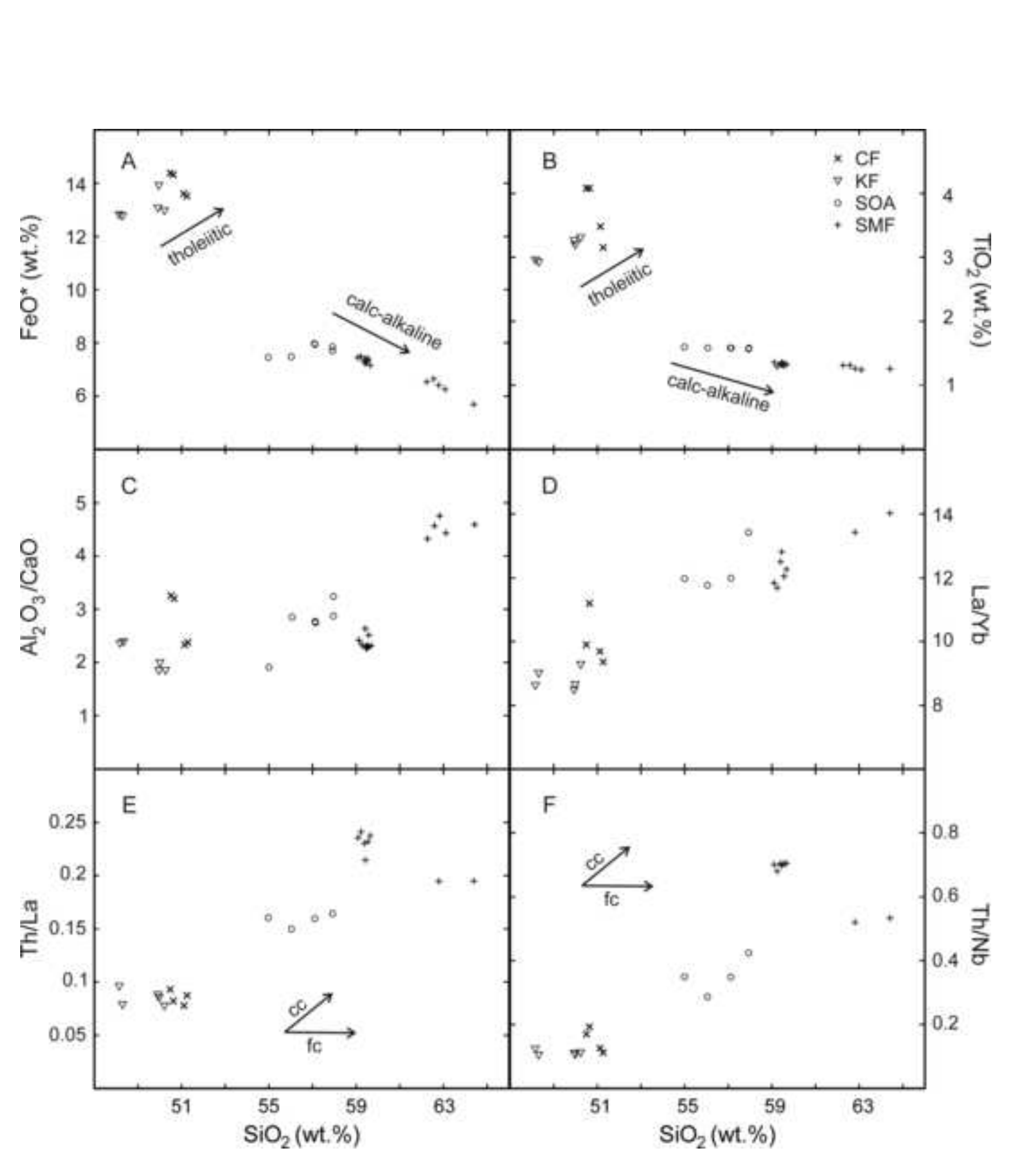

Figure 4

\section{Figure 4}

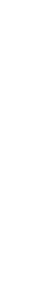

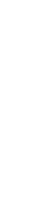

. 


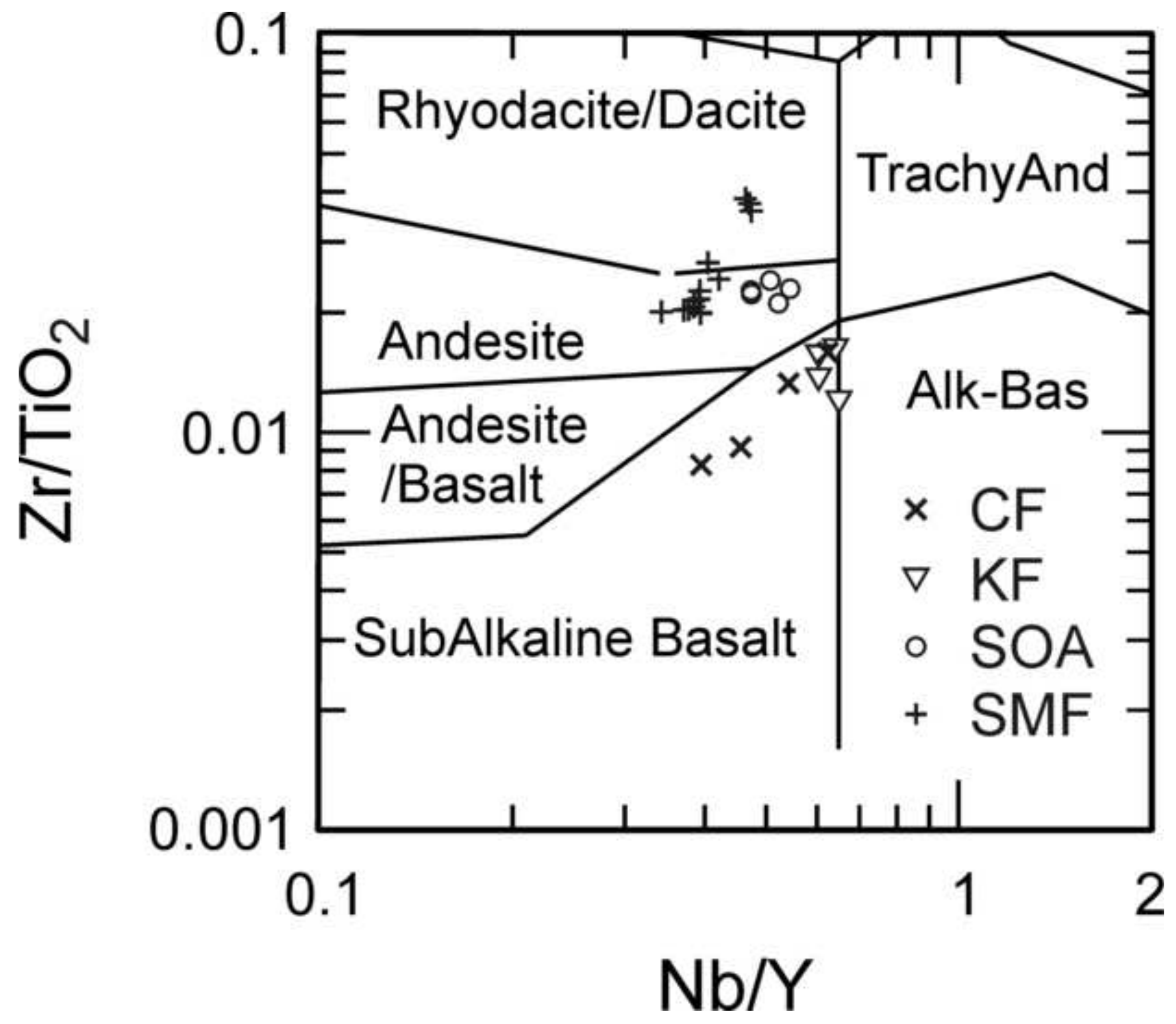




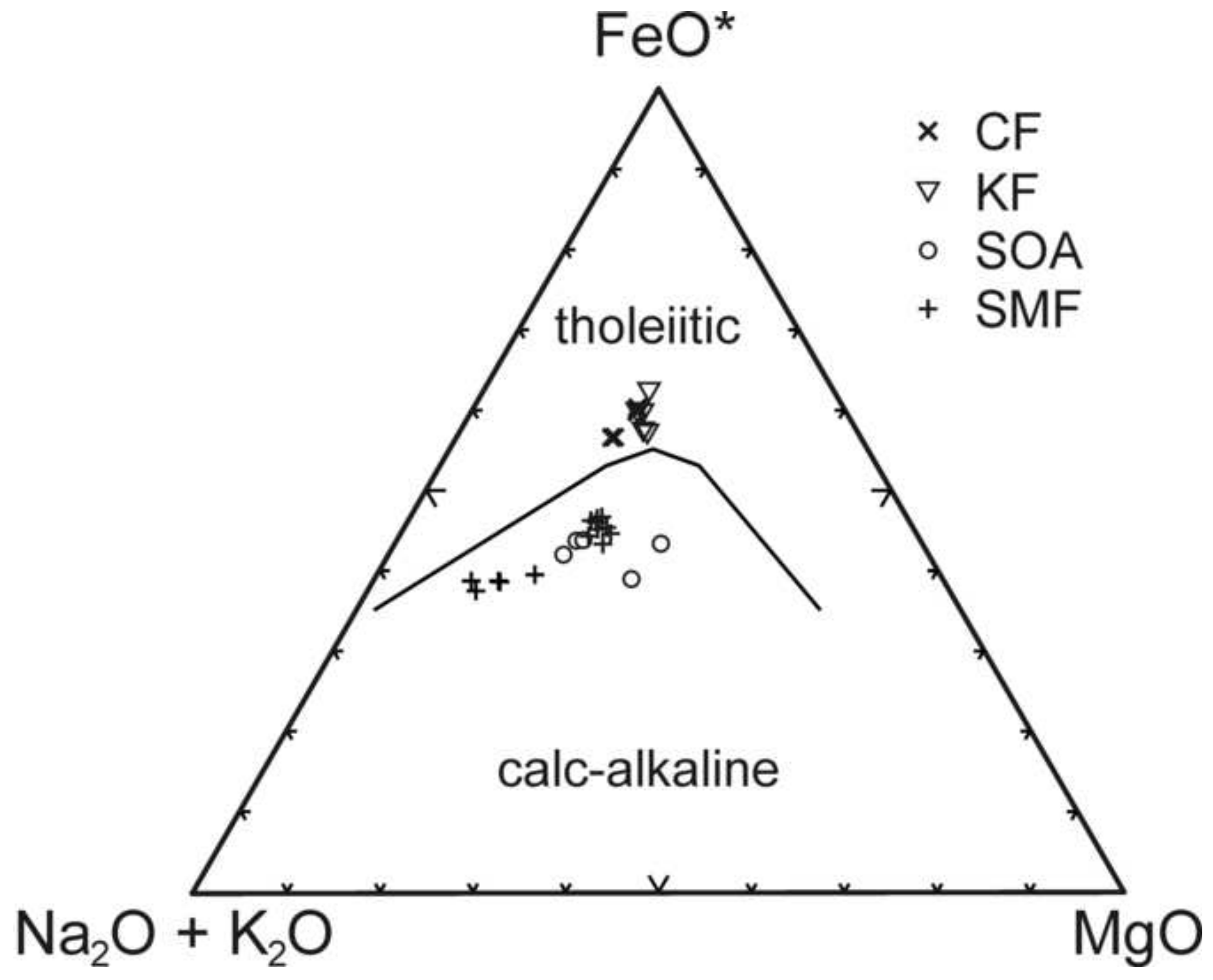




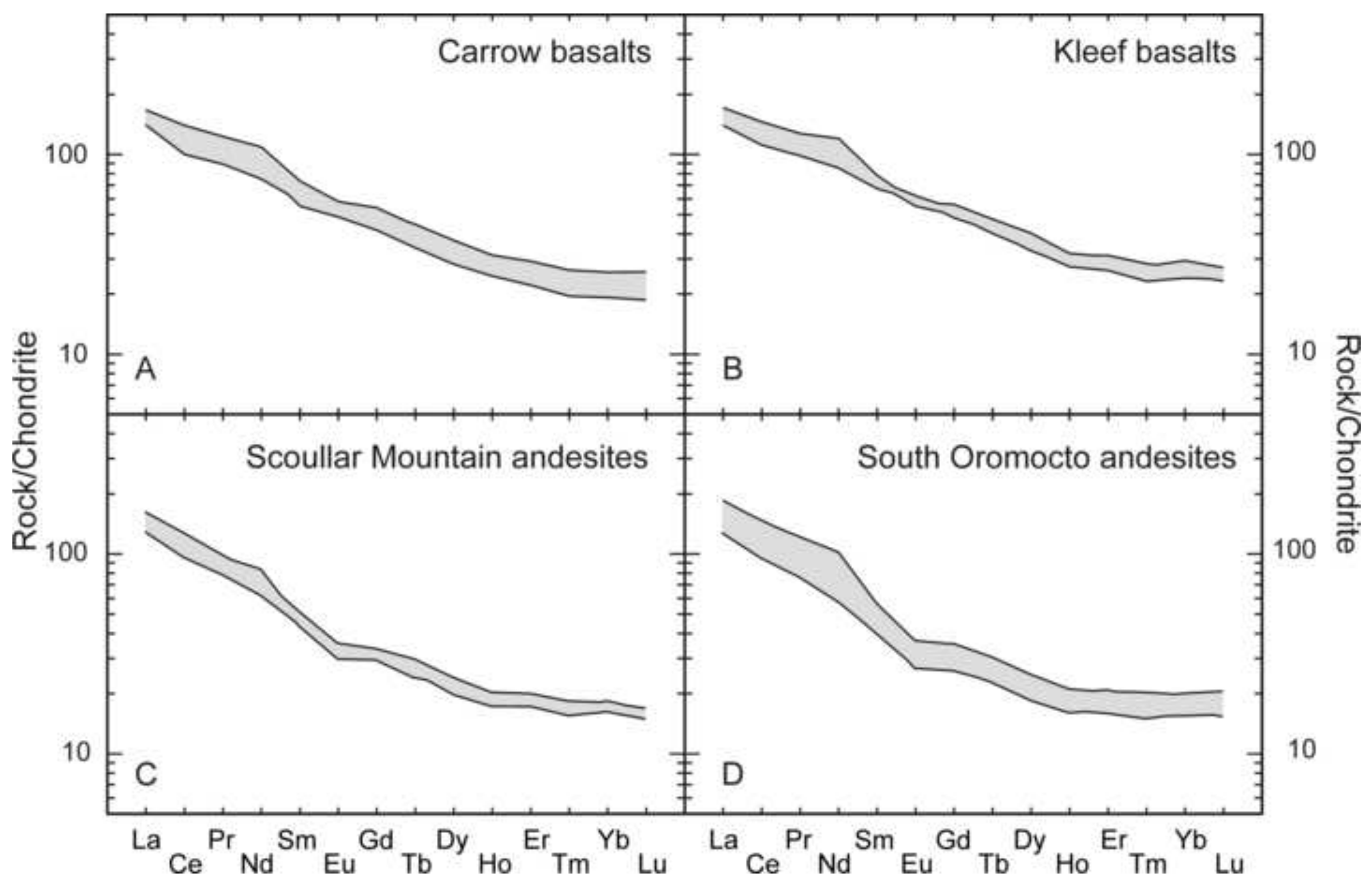




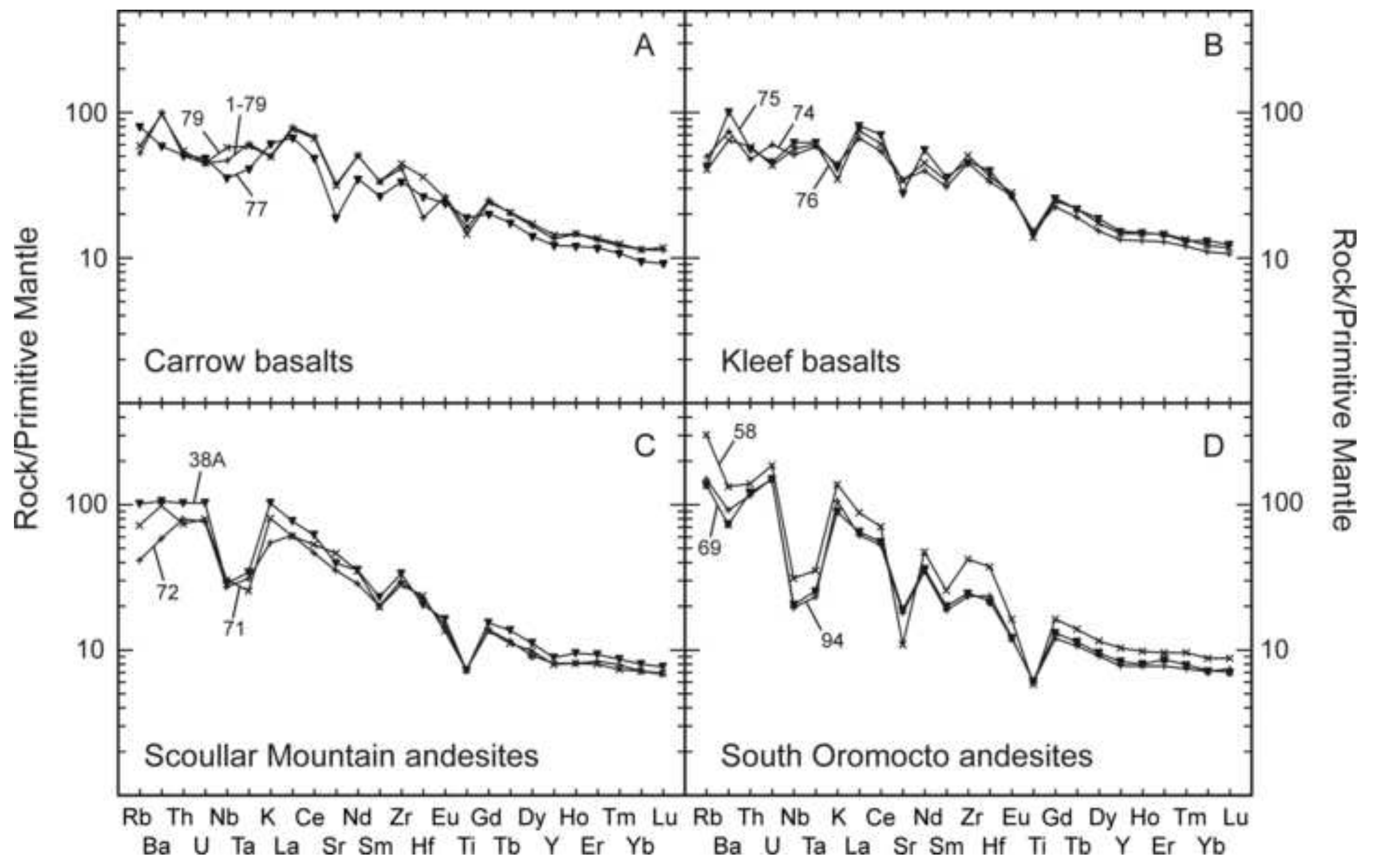




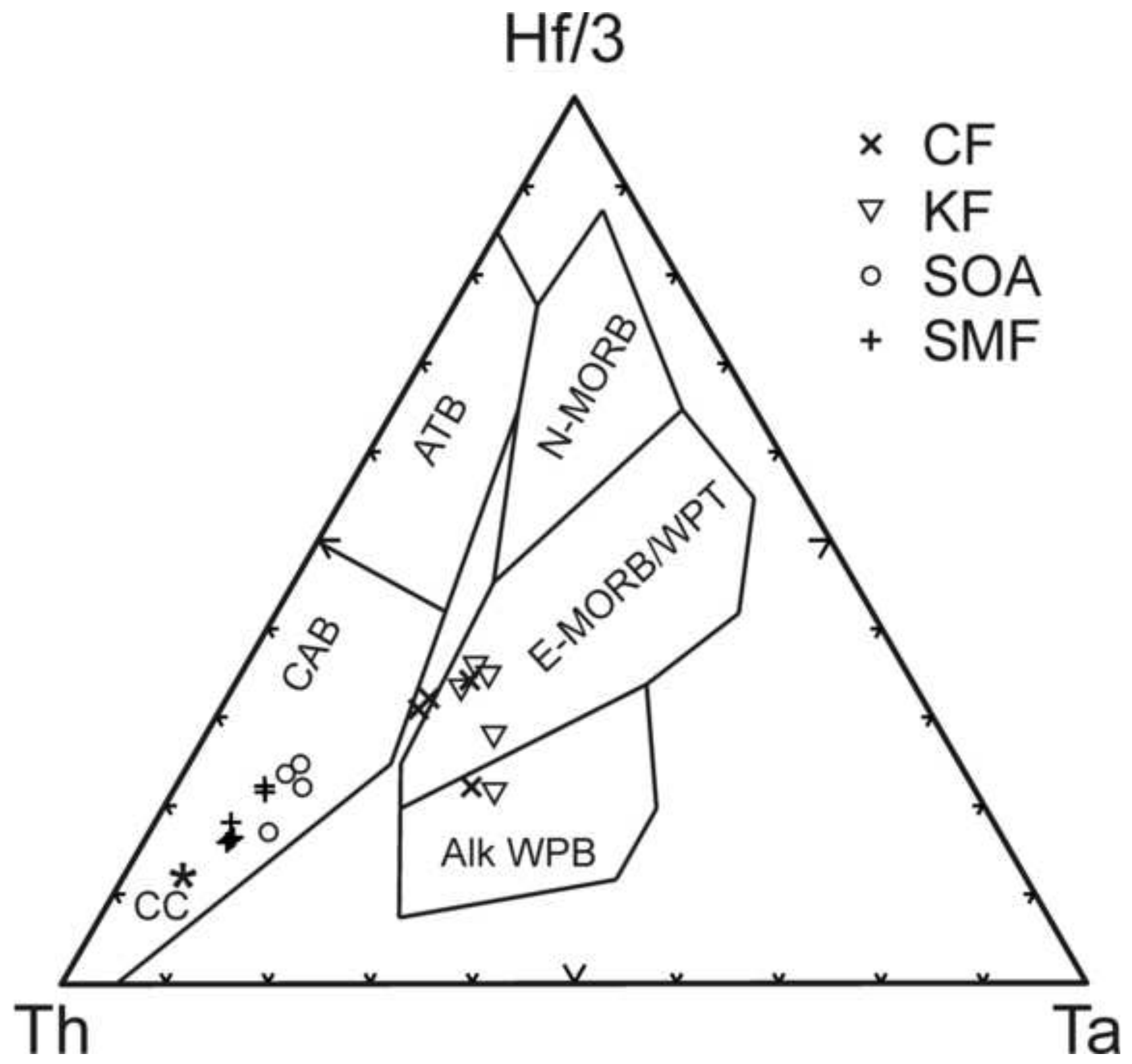



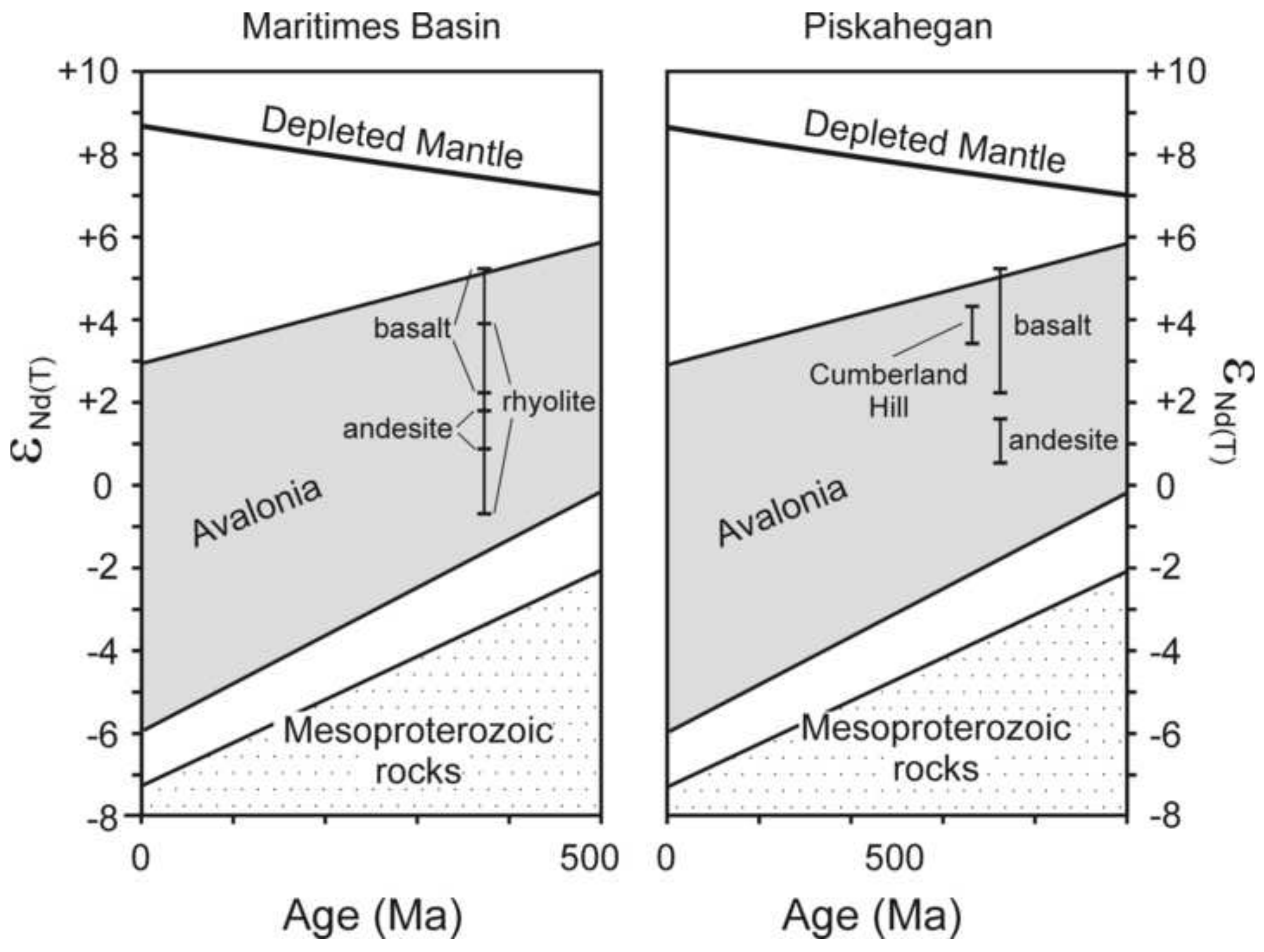


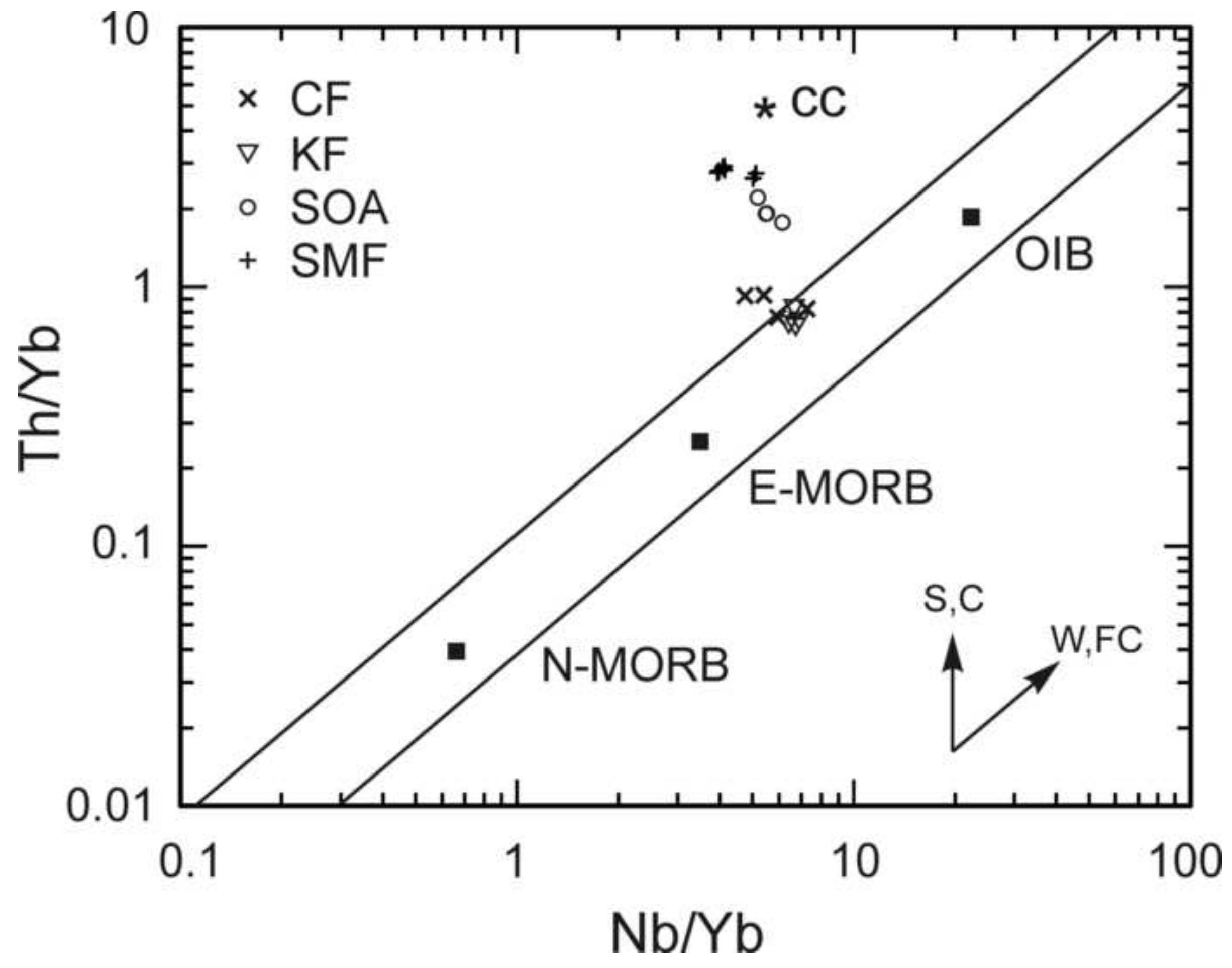




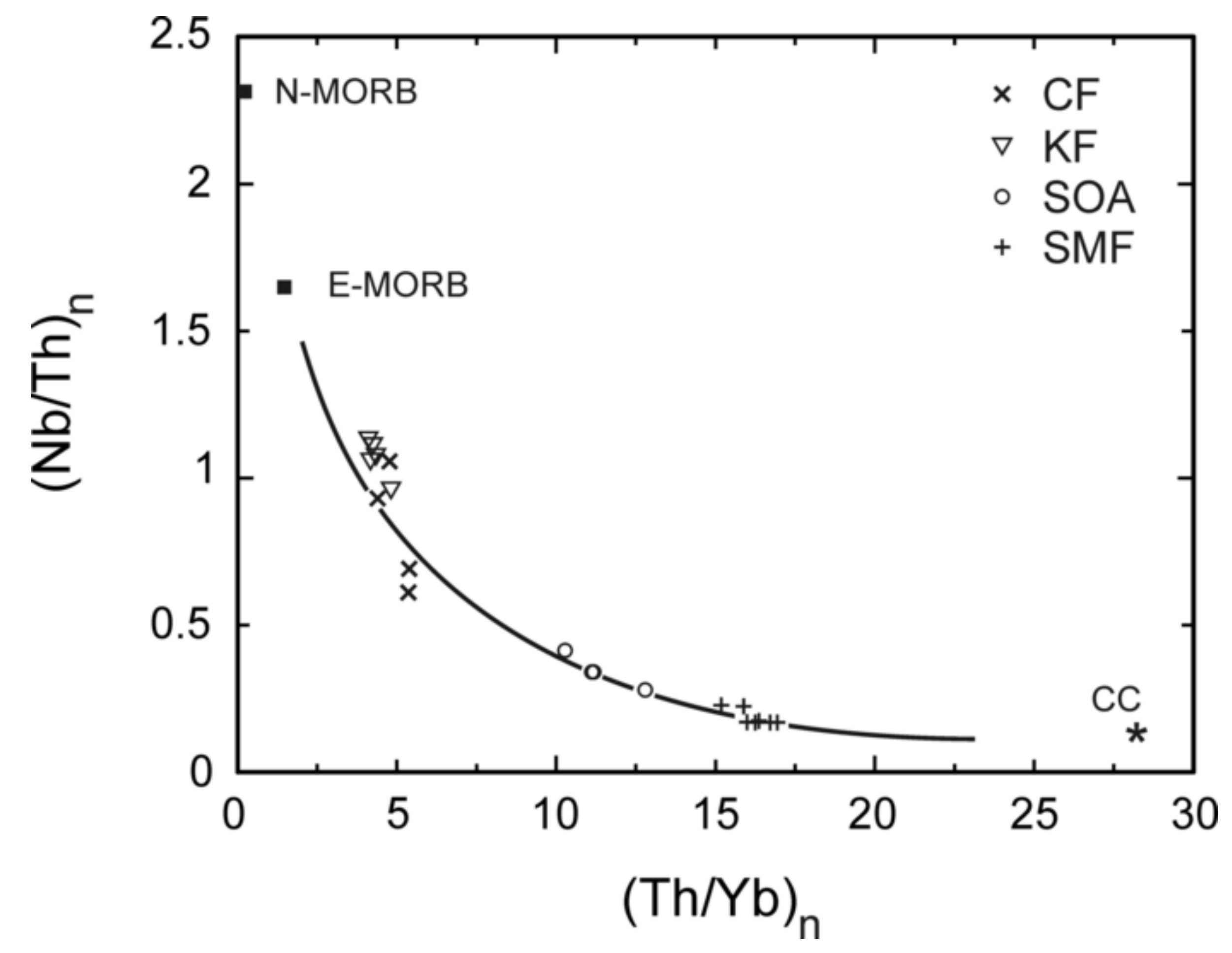




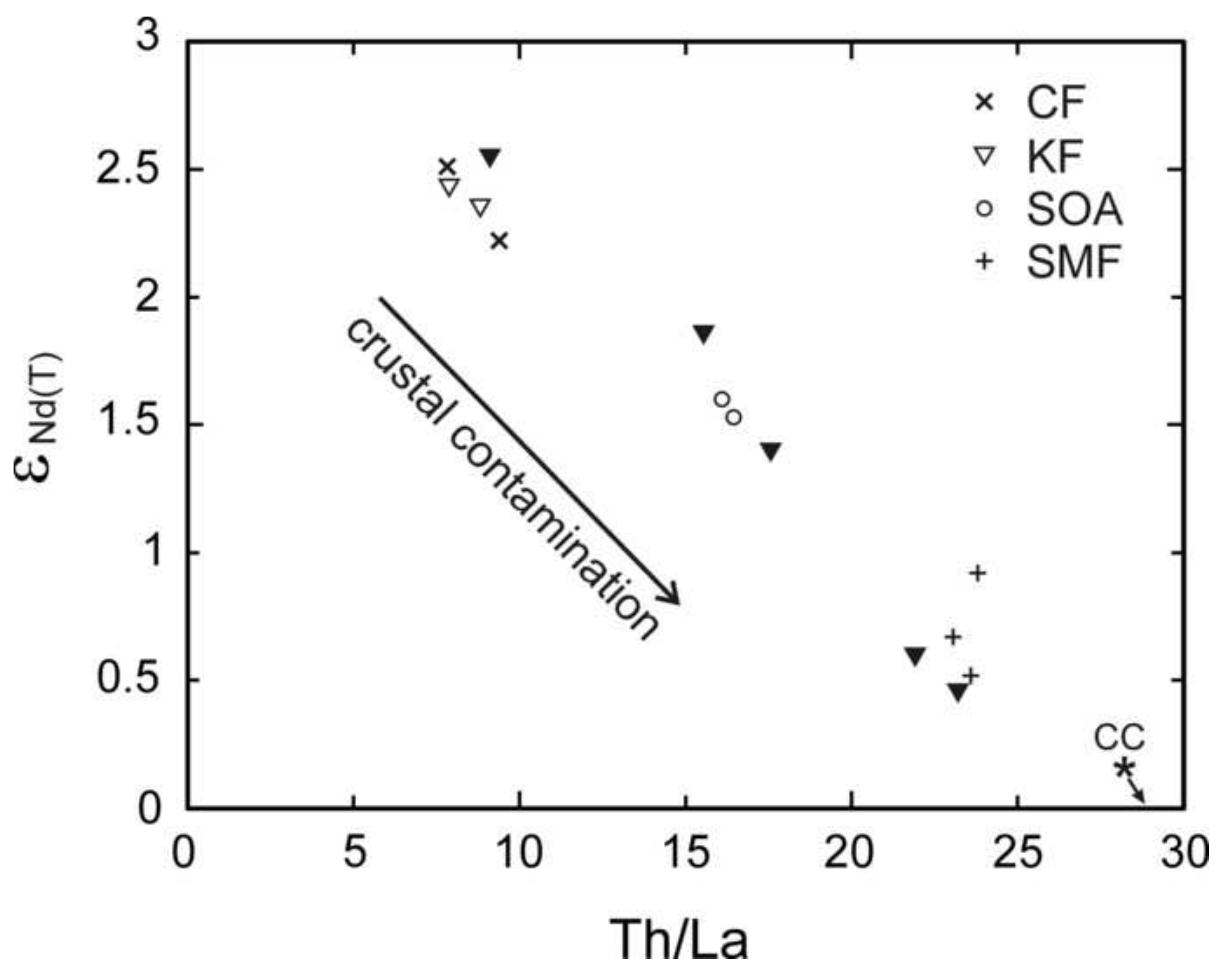


Table 1. Compositions and structural formulas of clinopyroxenes from andesites of the Piskahegan Group

South Oromocto Andesite

\begin{tabular}{rrrrrr}
\cline { 5 - 6 }$(w \mathrm{wt} \%)$ & \multicolumn{2}{c}{$38 \mathrm{~A}$} & & \multicolumn{2}{c}{$38 \mathrm{~B}$} \\
\cline { 6 - 7 } \cline { 5 - 6 } & average & sd & & average & \multicolumn{1}{l}{ s.d. } \\
$\mathrm{SiO}_{2}$ & 50.40 & 0.49 & & 50.54 & 0.50 \\
$\mathrm{TiO}_{2}$ & 0.87 & 0.10 & & 0.65 & 0.15 \\
$\mathrm{Al}_{2} \mathrm{O}_{3}$ & 2.79 & 1.79 & & 3.51 & 0.26 \\
$\mathrm{Cr}_{2} \mathrm{O}_{3}$ & 0.09 & 0.07 & & 0.35 & 0.24 \\
$\mathrm{FeO}^{\mathrm{t}}$ & 10.75 & 1.00 & & 8.08 & 2.20 \\
$\mathrm{MnO}$ & 0.31 & 0.02 & & 0.20 & 0.09 \\
$\mathrm{MgO}$ & 15.05 & 1.29 & & 15.84 & 1.02 \\
$\mathrm{NiO}$ & 0.02 & 0.02 & & 0.03 & 0.01 \\
$\mathrm{CaO}$ & 18.01 & 1.30 & & 19.43 & 0.91 \\
$\mathrm{Na}_{2} \mathrm{O}$ & 0.53 & 0.52 & & 0.46 & 0.09 \\
$\mathrm{~K}_{2} \mathrm{O}$ & 0.05 & 0.05 & & 0.02 & 0.01 \\
$\Sigma$ & 98.86 & & & 99.11 &
\end{tabular}

10

1.877

0.018

0.154

0.080

0.010

0.172

0.006

0.877

0.773

0.033

0.001

4.00

42.44

48.15

9.42

\begin{tabular}{|c|c|}
\hline \multicolumn{2}{|c|}{$38 \mathrm{C}$} \\
\hline average & s.d. \\
\hline 50.89 & 1.02 \\
\hline 0.64 & 0.22 \\
\hline 2.20 & 1.16 \\
\hline 0.08 & 0.07 \\
\hline 9.65 & 1.32 \\
\hline 0.30 & 0.07 \\
\hline 15.76 & 0.75 \\
\hline 19.13 & 0.74 \\
\hline 0.39 & 0.11 \\
\hline 0.02 & 0.00 \\
\hline 99.06 & \\
\hline
\end{tabular}

11

1.900

0.018

0.097

0.094

0.002

0.208

0.010

0.877

0.765

0.028

0.001

4.00

41.37

47.40

11.22

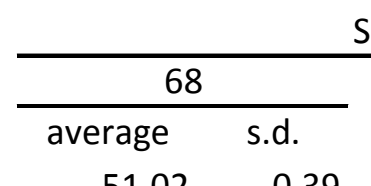

$51.02 \quad 0.39$

$0.71 \quad 0.11$

$2.04 \quad 0.34$

$0.21 \quad 0.20$

$9.50 \quad 1.90$

$0.26 \quad 0.06$

$15.87 \quad 0.80$

$0.01 \quad 0.01$

$19.40 \quad 0.57$

$0.27 \quad 0.02$

$0.02 \quad 0.01$

99.31

16

1.902

0.020

0.089

0.081

0.006

0.215

0.008

0.882

0.775

0.020

0.001

4.00

41.39

47.13

11.48
Scoullar Mountain Formation

\begin{tabular}{|c|c|c|c|}
\hline \multicolumn{2}{|c|}{69} & \multicolumn{2}{|c|}{92} \\
\hline average & s.d. & average & s.d. \\
\hline 51.00 & 0.32 & 51.09 & 0.31 \\
\hline 0.70 & 0.10 & 0.70 & 0.15 \\
\hline 2.31 & 0.42 & 1.84 & 0.44 \\
\hline 0.26 & 0.15 & 0.08 & 0.15 \\
\hline 8.62 & 0.78 & 10.75 & 1.69 \\
\hline 0.25 & 0.04 & 0.29 & 0.07 \\
\hline 16.07 & 0.51 & 15.03 & 1.03 \\
\hline 0.01 & 0.01 & 0.03 & 0.02 \\
\hline 19.59 & 0.22 & 19.22 & 0.51 \\
\hline 0.26 & 0.02 & 0.27 & 0.02 \\
\hline 0.02 & 0.01 & 0.02 & 0.02 \\
\hline 99.08 & & 99.32 & \\
\hline 16 & & 21 & \\
\hline 1.901 & & 1.917 & \\
\hline 0.020 & & 0.020 & \\
\hline 0.101 & & 0.081 & \\
\hline 0.070 & & 0.064 & \\
\hline 0.008 & & 0.002 & \\
\hline 0.199 & & 0.273 & \\
\hline 0.008 & & 0.009 & \\
\hline 0.893 & & 0.840 & \\
\hline 0.782 & & 0.773 & \\
\hline 0.018 & & 0.020 & \\
\hline 0.010 & & 0.001 & \\
\hline 4.01 & & 4.00 & \\
\hline 41.74 & & 40.97 & \\
\hline 47.65 & & 44.55 & \\
\hline 10.61 & & 14.48 & \\
\hline
\end{tabular}

$\mathrm{n}$ = number of crystals; each crystal had four analyses; average is the arithmatic mean; s.d. = standard deviation; formulas based upon 6 oxygens; Endmember components: Wo - wollastonite; En - enstatite; Fs - ferrosilite; $\mathrm{FeO}^{\mathrm{t}}$ - total Fe as $\mathrm{FeO}$ 
Table 2. Major and trace element compostions of mafic and intermediate rocks of the Piskahegan Group

\begin{tabular}{|c|c|c|c|c|c|c|c|c|c|}
\hline \multirow{3}{*}{$\begin{array}{r}\text { Sample \# } \\
\mathrm{SiO}_{2} \text { (wt.\%) }\end{array}$} & \multicolumn{4}{|c|}{ Carrow Formation } & \multicolumn{5}{|c|}{ Kleef Formation } \\
\hline & 77 & 79 & $1-77$ & $1-79$ & 74 & 75 & 76 & $1-74$ & $1-76$ \\
\hline & 47.64 & 48.87 & 47.93 & 49.08 & 47.87 & 47.57 & 45.45 & 48.09 & 45.60 \\
\hline $\mathrm{TiO}_{2}$ & 3.85 & 3.00 & 3.86 & 3.34 & 3.12 & 3.04 & 2.79 & 3.16 & 2.76 \\
\hline $\mathrm{Al}_{2} \mathrm{O}_{3}$ & 13.77 & 14.41 & 13.76 & 14.36 & 14.65 & 14.53 & 16.49 & 14.58 & 16.65 \\
\hline $\mathrm{FeO}^{*}$ & 13.55 & 12.88 & 13.54 & 13.06 & 12.51 & 13.23 & 12.07 & 12.39 & 12.03 \\
\hline $\mathrm{MnO}$ & 0.16 & 0.24 & 0.17 & 0.24 & 0.18 & 0.28 & 0.26 & 0.17 & 0.26 \\
\hline $\mathrm{MgO}$ & 4.12 & 3.88 & 4.01 & 3.85 & 3.92 & 3.82 & 4.33 & 3.75 & 4.17 \\
\hline $\mathrm{CaO}$ & 4.24 & 6.08 & 4.31 & 6.18 & 7.99 & 7.35 & 7.03 & 7.95 & 7.02 \\
\hline $\mathrm{Na}_{2} \mathrm{O}$ & 4.59 & 3.40 & 4.62 & 3.35 & 3.33 & 3.03 & 3.81 & 3.33 & 3.81 \\
\hline $\mathrm{K}_{2} \mathrm{O}$ & 1.74 & 1.43 & 1.80 & 1.45 & 1.26 & 1.18 & 0.98 & 1.31 & 1.00 \\
\hline $\mathrm{P}_{2} \mathrm{O}_{5}$ & 0.68 & 1.13 & 0.65 & 1.09 & 1.01 & 1.13 & 1.14 & 0.98 & 1.07 \\
\hline LOI & 4.00 & 3.40 & 3.50 & 2.61 & 2.40 & 3.50 & 4.20 & 2.14 & 3.79 \\
\hline$\Sigma$ & 98.34 & 98.72 & 98.15 & 98.61 & 98.24 & 98.66 & 98.55 & 97.86 & 98.16 \\
\hline $\mathrm{Mg} \#$ & 0.35 & 0.35 & 0.35 & 0.34 & 0.36 & 0.34 & 0.39 & 0.35 & 0.38 \\
\hline $\mathrm{Cr}(\mathrm{ppm})$ & 0 & 8 & 30 & 30 & 19 & 6 & 6 & 40 & 30 \\
\hline $\mathrm{Ni}$ & 16 & 16 & 60 & 60 & 21 & 17 & 18 & 60 & 30 \\
\hline Co & 50 & 31 & 40 & 27 & 30 & 32 & 29 & 29 & 29 \\
\hline V & 393 & 204 & 421 & 208 & 247 & 205 & 196 & 247 & 192 \\
\hline $\mathrm{Pb}$ & 34 & 3 & 31 & 12 & 13 & 12 & 30 & 9 & 36 \\
\hline $\mathrm{Zn}$ & 417 & 160 & 420 & 170 & 146 & 162 & 153 & 160 & 160 \\
\hline $\mathrm{Rb}$ & 48 & 36 & 42 & 32 & 30 & 26 & 24 & 28 & 23 \\
\hline $\mathrm{Ba}$ & 386 & 645 & 447 & 670 & 493 & 672 & 422 & 529 & 472 \\
\hline $\mathrm{Sr}$ & 374 & 630 & 387 & 649 & 691 & 555 & 672 & 714 & 701 \\
\hline $\mathrm{Ga}$ & 23 & 22 & 24 & 23 & 21 & 21 & 22 & 23 & 26 \\
\hline $\mathrm{Ta}$ & 1.58 & 2.30 & 1.50 & 2.40 & 2.27 & 2.40 & 2.32 & 2.30 & 2.60 \\
\hline $\mathrm{Nb}$ & 23.7 & 39.0 & 19.0 & 32.0 & 34.7 & 42.0 & 37.4 & 32.0 & 37.0 \\
\hline $\mathrm{Hf}$ & 7.7 & 10.6 & 7.5 & 5.6 & 9.8 & 11.6 & 10.5 & 6.9 & 5.4 \\
\hline $\mathrm{Zr}$ & 352 & 474 & 319 & 443 & 478 & 484 & 531 & 426 & 325 \\
\hline Y & 52 & 62 & 48 & 59 & 57 & 66 & 63 & 53 & 57 \\
\hline Th & 4.08 & 4.40 & 3.70 & 4.10 & 3.85 & 4.50 & 4.65 & 3.60 & 3.90 \\
\hline$U$ & 0.96 & 0.90 & 0.90 & 0.90 & 1.20 & 0.90 & 0.85 & 1.20 & 0.90 \\
\hline $\mathrm{La}$ & 43.5 & 50.2 & 44.8 & 52.4 & 43.6 & 52.7 & 48.3 & 46.4 & 49.5 \\
\hline $\mathrm{Ce}$ & 81.6 & 112 & 90.5 & 116 & 91.6 & 118 & 101 & 105 & 112 \\
\hline $\mathrm{Pr}$ & 11.0 & 14.7 & 12.1 & 15.3 & 12.1 & 15.6 & 13.4 & 13.8 & 14.3 \\
\hline $\mathrm{Nd}$ & 44.7 & 64.8 & 50.4 & 65.5 & 51.2 & 71.2 & 56.9 & 58.3 & 60.8 \\
\hline Sm & 11.1 & 14.2 & 10.6 & 14.3 & 13.0 & 15.0 & 14.1 & 13.6 & 14.0 \\
\hline $\mathrm{Eu}$ & 3.77 & 4.11 & 3.54 & 4.26 & 4.29 & 4.19 & 4.42 & 4.03 & 4.01 \\
\hline $\mathrm{Gd}$ & 11.3 & 13.6 & 10.9 & 14.3 & 12.7 & 14.5 & 13.8 & 13.0 & 13.9 \\
\hline $\mathrm{Tb}$ & 1.78 & 2.12 & 1.60 & 2.10 & 1.95 & 2.21 & 2.20 & 1.90 & 2.10 \\
\hline Dy & 9.77 & 12.1 & 9.10 & 11.7 & 10.7 & 12.9 & 11.9 & 10.8 & 11.9 \\
\hline Ho & 1.86 & 2.29 & 1.80 & 2.30 & 2.04 & 2.30 & 2.25 & 2.00 & 2.20 \\
\hline $\mathrm{Er}$ & 5.31 & 6.24 & 4.70 & 6.10 & 5.87 & 6.53 & 6.54 & 5.60 & 6.10 \\
\hline $\mathrm{Tm}$ & 0.75 & 0.88 & 0.65 & 0.86 & 0.84 & 0.91 & 0.93 & 0.77 & 0.87 \\
\hline $\mathrm{Yb}$ & 4.39 & 5.36 & 4.00 & 5.40 & 5.14 & 6.09 & 5.60 & 5.00 & 5.50 \\
\hline Lu & 0.64 & 0.83 & 0.60 & 0.80 & 0.75 & 0.86 & 0.81 & 0.76 & 0.80 \\
\hline
\end{tabular}

$\mathrm{FeO}^{*}$ - total $\mathrm{Fe}$ as $\mathrm{FeO}$; $\mathrm{LOI}$ - loss on ignition; $\mathrm{Mg} \#=\mathrm{MgO} /\left(\mathrm{MgO}+\mathrm{FeO}^{*}\right) \mathrm{mol} \%$; major element oxides are not recalculated to $100 \%$ 
Table 2 cont. Major and trace element compostions of mafic and intermediate rocks of the Piskahegan Group

\begin{tabular}{|c|c|c|c|c|c|c|c|c|c|c|c|c|}
\hline \multirow[b]{2}{*}{ Sample \# } & \multicolumn{4}{|c|}{ South Oromocto andesite } & \multicolumn{8}{|c|}{ Scoullar Mountain Formation } \\
\hline & 71 & 72 & $38-C$ & $38 \mathrm{~A}$ & 56 & 58 & $1-60$ & 61 & 68 & 69 & 94 & 96 \\
\hline $\mathrm{SiO}_{2}$ (wt.\%) & 53.73 & 52.37 & 55.15 & 55.91 & 56.65 & 56.33 & 56.54 & 55.60 & 57.12 & 56.74 & 62.51 & 60.21 \\
\hline $\mathrm{TiO}_{2}$ & 1.52 & 1.52 & 1.53 & 1.51 & 1.26 & 1.24 & 1.28 & 1.28 & 1.25 & 1.27 & 1.22 & 1.21 \\
\hline $\mathrm{Al}_{2} \mathrm{O}_{3}$ & 15.91 & 15.94 & 15.85 & 15.70 & 15.02 & 14.91 & 15.30 & 15.06 & 14.88 & 15.16 & 14.76 & 14.85 \\
\hline $\mathrm{FeO}^{*}$ & 7.16 & 7.10 & 7.67 & 7.57 & 6.80 & 6.99 & 6.87 & 7.00 & 7.22 & 6.98 & 5.51 & 6.15 \\
\hline $\mathrm{MnO}$ & 0.16 & 0.17 & 0.14 & 0.14 & 0.13 & 0.12 & 0.13 & 0.12 & 0.14 & 0.12 & 0.11 & 0.13 \\
\hline $\mathrm{MgO}$ & 5.12 & 4.70 & 3.43 & 3.46 & 3.17 & 3.57 & 2.95 & 3.38 & 3.34 & 3.64 & 1.74 & 2.16 \\
\hline $\mathrm{CaO}$ & 5.60 & 8.36 & 5.78 & 5.48 & 6.51 & 5.95 & 6.67 & 6.25 & 6.40 & 5.77 & 3.22 & 3.13 \\
\hline $\mathrm{Na}_{2} \mathrm{O}$ & 3.84 & 3.03 & 3.48 & 3.24 & 2.17 & 2.15 & 2.06 & 1.92 & 3.20 & 2.98 & 3.47 & 3.86 \\
\hline $\mathrm{K}_{2} \mathrm{O}$ & 2.33 & 1.57 & 3.01 & 2.99 & 2.94 & 3.00 & 3.02 & 3.15 & 2.57 & 2.56 & 4.03 & 3.73 \\
\hline $\mathrm{P}_{2} \mathrm{O}_{5}$ & 0.49 & 0.49 & 0.50 & 0.50 & 0.30 & 0.30 & 0.28 & 0.31 & 0.30 & 0.31 & 0.47 & 0.44 \\
\hline LOI & 3.20 & 3.80 & 3.00 & 2.70 & 4.80 & 4.80 & 4.51 & 5.40 & 2.10 & 2.80 & 1.00 & 2.70 \\
\hline$\Sigma$ & 99.06 & 99.04 & 99.54 & 99.20 & 99.74 & 99.37 & 99.62 & 99.47 & 98.51 & 98.33 & 98.05 & 98.56 \\
\hline $\mathrm{Mg} \#$ & 0.56 & 0.54 & 0.44 & 0.45 & 0.45 & 0.48 & 0.43 & 0.46 & 0.45 & 0.48 & 0.36 & 0.39 \\
\hline $\mathrm{Cr}(\mathrm{ppm})$ & 58 & 61 & 24 & 21 & 75 & 81 & 90 & 70 & 88 & 64 & 19 & 26 \\
\hline $\mathrm{Ni}$ & 42 & 38 & 20 & 24 & 15 & 15 & 30 & 22 & 28 & 15 & 7 & 8 \\
\hline Co & 24 & 24 & 26 & 20 & 27 & 24 & 21 & 26 & 25 & 22 & 15 & 13 \\
\hline V & 162 & 163 & 145 & 140 & 163 & 147 & 166 & 161 & 155 & 154 & 91 & 98 \\
\hline $\mathrm{Pb}$ & 0 & 8 & 4 & 13 & 12 & 17 & 18 & 12 & 12 & 12 & 18 & 17 \\
\hline $\mathrm{Zn}$ & 95 & 92 & 95 & 95 & 78 & 79 & 80 & 78 & 81 & 79 & 88 & 91 \\
\hline $\mathrm{Rb}$ & 44 & 25 & 65 & 62 & 79 & 90 & 74 & 100 & 82 & 83 & 187 & 151 \\
\hline $\mathrm{Ba}$ & 659 & 388 & 751 & 713 & 556 & 606 & 606 & 599 & 476 & 489 & 901 & 899 \\
\hline $\mathrm{Sr}$ & 936 & 707 & 835 & 805 & 346 & 359 & 356 & 322 & 409 & 381 & 223 & 360 \\
\hline $\mathrm{Ga}$ & 17 & 19 & 20 & 17 & 17 & 18 & 18 & 20 & 19 & 17 & 17 & 18 \\
\hline $\mathrm{Ta}$ & 1.00 & 1.21 & 1.10 & 1.35 & 0.99 & 0.90 & 1.00 & 1.02 & 1.01 & 1.00 & 1.40 & 1.40 \\
\hline $\mathrm{Nb}$ & 20.8 & 18.4 & 21.2 & 19.7 & 13.3 & 13.2 & 13.0 & 13.4 & 14.2 & 13.9 & 21.5 & 21.1 \\
\hline $\mathrm{Hf}$ & 7.0 & 6.6 & 8.0 & 6.1 & 6.1 & 6.9 & 6.1 & 6.1 & 6.2 & 6.4 & 11.2 & 10.4 \\
\hline $\mathrm{Zr}$ & 300 & 319 & 348 & 362 & 272 & 248 & 255 & 272 & 282 & 263 & 458 & 434 \\
\hline Y & 35 & 35 & 39 & 39 & 34 & 34 & 33 & 35 & 36 & 36 & 46 & 45 \\
\hline Th & 6.00 & 6.45 & 7.40 & 8.39 & 9.40 & 9.30 & 9.10 & 9.41 & 9.68 & 9.80 & 11.50 & 11.00 \\
\hline U & 1.60 & 1.53 & 1.90 & 2.08 & 2.91 & 3.00 & 2.80 & 2.80 & 2.74 & 3.00 & 3.80 & 3.60 \\
\hline La & 39.9 & 40.1 & 46.3 & 51.0 & 39.5 & 40.0 & 42.3 & 39.9 & 40.1 & 42.5 & 58.9 & 56.4 \\
\hline $\mathrm{Ce}$ & 90.4 & 78.7 & 101 & 106 & 78.2 & 88.3 & 90.4 & 79.1 & 79.4 & 94.3 & 122 & 122 \\
\hline $\operatorname{Pr}$ & 10.8 & 9.65 & 12.0 & 12.3 & 9.42 & 10.5 & 10.7 & 9.36 & 9.53 & 11.2 & 15.3 & 14.8 \\
\hline $\mathrm{Nd}$ & 45.4 & 36.8 & 50.5 & 46.5 & 35.7 & 44.6 & 40.4 & 34.7 & 35.2 & 46.8 & 62.1 & 60.6 \\
\hline $\mathrm{Sm}$ & 8.43 & 8.49 & 9.26 & 9.92 & 7.67 & 7.87 & 8.00 & 7.61 & 7.97 & 8.47 & 11.05 & 10.95 \\
\hline $\mathrm{Eu}$ & 2.18 & 2.36 & 2.34 & 2.64 & 1.97 & 1.95 & 2.01 & 2.11 & 2.07 & 1.94 & 2.66 & 2.70 \\
\hline $\mathrm{Gd}$ & 7.74 & 7.80 & 8.16 & 8.84 & 7.05 & 6.76 & 7.00 & 7.25 & 7.13 & 7.48 & 9.46 & 9.29 \\
\hline $\mathrm{Tb}$ & 1.15 & 1.18 & 1.29 & 1.42 & 1.08 & 1.09 & 1.10 & 1.16 & 1.09 & 1.17 & 1.46 & 1.44 \\
\hline Dy & 6.97 & 6.42 & 7.43 & 7.93 & 6.15 & 6.33 & 6.10 & 6.82 & 6.10 & 6.71 & 8.26 & 8.16 \\
\hline Ho & 1.27 & 1.26 & 1.32 & 1.50 & 1.18 & 1.20 & 1.20 & 1.27 & 1.19 & 1.25 & 1.56 & 1.51 \\
\hline Er & 3.68 & 3.81 & 3.97 & 4.31 & 3.53 & 3.52 & 3.40 & 3.74 & 3.54 & 3.94 & 4.46 & 4.45 \\
\hline $\mathrm{Tm}$ & 0.52 & 0.56 & 0.56 & 0.62 & 0.51 & 0.52 & 0.50 & 0.54 & 0.53 & 0.56 & 0.69 & 0.65 \\
\hline $\mathrm{Yb}$ & 3.39 & 3.35 & 3.86 & 3.80 & 3.22 & 3.32 & 3.30 & 3.37 & 3.43 & 3.40 & 4.20 & 4.20 \\
\hline Lu & 0.49 & 0.48 & 0.54 & 0.55 & 0.50 & 0.52 & 0.51 & 0.49 & 0.51 & 0.50 & 0.63 & 0.66 \\
\hline
\end{tabular}

$\mathrm{FeO}^{*}$ - total Fe as FeO; LOI - loss on ignition; $\mathrm{Mg} \#=\mathrm{MgO} /\left(\mathrm{MgO}_{\mathrm{FeO}}{ }^{*}\right) \mathrm{mol} \%$; major element oxides are not recalculated to $100 \%$ 
Table 3. Sm-Nd isotopic data for volcanic rocks of the Piskahegan Group and Cumberland Hill Formation

\begin{tabular}{|c|c|c|c|c|c|c|c|c|c|}
\hline Sample & $\begin{array}{c}\mathrm{Nd} \\
(\mathrm{ppm})\end{array}$ & $\begin{array}{c}\text { Sm } \\
(\mathrm{ppm})\end{array}$ & ${ }^{147} \mathrm{Sm} /{ }^{144} \mathrm{Nd}$ & ${ }^{143} \mathrm{Nd} /{ }^{144} \mathrm{Nd}_{\mathrm{m}}$ & $2 \sigma$ & ${ }^{143} \mathrm{Nd} /{ }^{144} \mathrm{Nd}_{\mathrm{i}}$ & $\varepsilon_{\mathrm{Nd}(\mathrm{T})}$ & $\begin{array}{l}\mathrm{T}_{\mathrm{DM} 1} \\
(\mathrm{Ma})\end{array}$ & $\begin{array}{l}\mathrm{T}_{\mathrm{DM} 2} \\
(\mathrm{Ma})\end{array}$ \\
\hline \multicolumn{10}{|c|}{ Carrow Fm (basalts) } \\
\hline 77 & 48.3 & 10.4 & 0.1302 & 0.512593 & 6 & 0.512282 & 2.22 & 1016 & 831 \\
\hline $1-79$ & 62.1 & 13.7 & 0.1337 & 0.512616 & 6 & 0.512296 & 2.51 & 1017 & 824 \\
\hline \multicolumn{10}{|c|}{ Kleef Fm (basalts) } \\
\hline 74 & 58.5 & 13.2 & 0.1368 & 0.512615 & 8 & 0.512288 & 2.35 & 1059 & 857 \\
\hline $1-76$ & 60.7 & 13.4 & 0.1338 & 0.512612 & 7 & 0.512292 & 2.43 & 1025 & 832 \\
\hline \multicolumn{10}{|c|}{ South Oromocto Andesite Fm (andesites) } \\
\hline 72 & 40.8 & 8.02 & 0.1189 & 0.512534 & 6 & 0.512250 & 1.60 & 990 & 827 \\
\hline $38 \mathrm{~A}$ & 46.5 & 9.92 & 0.1291 & 0.512556 & 8 & 0.512247 & 1.55 & 1069 & 885 \\
\hline \multicolumn{10}{|c|}{ Scoullar Mt. Fm (andesites) } \\
\hline 61 & 39.6 & 7.63 & 0.1165 & 0.512473 & 6 & 0.512195 & 0.52 & 1061 & 900 \\
\hline 69 & 46.8 & 8.47 & 0.1095 & 0.512464 & 8 & 0.512202 & 0.67 & 1004 & 854 \\
\hline 56 & 39.0 & 7.48 & 0.1160 & 0.512492 & 6 & 0.512215 & 0.92 & 1026 & 867 \\
\hline \multicolumn{10}{|c|}{ Cumberland Hill Fm (trachytes) } \\
\hline $1-203$ & 104 & 20.9 & 0.1210 & 0.512690 & 7 & 0.512425 & 4.26 & 757 & 598 \\
\hline $1-208$ & 84.8 & 16.0 & 0.1137 & 0.512630 & 7 & 0.512381 & 3.40 & 793 & 644 \\
\hline
\end{tabular}

$\mathrm{T}_{\mathrm{DM} 1}$-depleted mantle model age calculated using a linear evolution for a mantle separated from the CHUR at $4.55 \mathrm{Ga}$ and having a present day $\varepsilon_{\mathrm{Nd}}$ value of $+10 ; \mathrm{T}_{\mathrm{DM} 2^{-}}$depleted mantle model age calculated using the model of DePaolo (1988); ${ }^{143} \mathrm{Nd} /{ }^{144} \mathrm{Nd}_{\mathrm{i}}$ and $\varepsilon_{\mathrm{Nd}(\mathrm{T})}$ values were calculated for the respective crystallization ages $(\mathrm{T}=365 \mathrm{Ma}$, Piskahegan Group; $\mathrm{T}=335 \mathrm{Ma}$, Cumberland Hill Formation); ${ }^{143} \mathrm{Nd} /{ }^{144} \mathrm{Nd}_{\mathrm{m}}$ - measured values; ${ }^{143} \mathrm{Nd} /{ }^{144} \mathrm{Nd}_{\mathrm{i}}$ - initial, calculated; $2 \sigma$ - uncertainty in measured ${ }^{143} \mathrm{Nd} /{ }^{144} \mathrm{Nd}$ - the value is the sixth decimal place; estimated precision of ${ }^{147} \mathrm{Sm} /{ }^{144} \mathrm{Nd}$ data is $+/-0.5 \%(2 \sigma)$ 